\title{
Solitary pulmonary nodules: morphological and metabolic characterisation by FDG-PET-MDCT
}

\section{Nodulo polmonare solitario: caratterizzazione morfologico-metabolica mediante imaging integrato TCms/FDG-PET}

\author{
A. Orlacchio • O. Schillaci • L. Antonelli • S. D’Urso • G. Sergiacomi • P. Nicolì • G. Simonetti \\ Dipartimento di Diagnostica per Immagini e Radiologia Interventistica, Policlinico Universitario “Tor Vergata”, Viale Oxford 81, \\ I-00133 Roma, Italy \\ Correspondence to: A. Orlacchio, Tel.: +39-06-2090-2400, Fax: +39-06-2090-2404, e-mail: aorlacchio@ sirm.org
}

Received: 12 May 2006 / Accepted: 16 June 2006 / Published online: 19 March 2007

\begin{abstract}
Purpose. This study was done to analyse the additional morphological and functional information provided by the integration of $\left[{ }^{18} \mathrm{~F}\right]$-2-fluoro-2-deoxy-D-glucose positron emission tomography $\left(\left[{ }^{18} \mathrm{~F}\right]-\mathrm{FDG}-\mathrm{PET}\right)$ with contrast-enhanced multidetector computed tomography (MDCT) in the characterisation of indeterminate solitary pulmonary nodules (SPNs).

Materials and methods. Fifty-six SPNs, previously classified as indeterminate, were evaluated using a Discovery ST16 PET/CT system (GE Medical Systems) with nonionic iodinated contrast material and $\left[{ }^{18} \mathrm{~F}\right]-\mathrm{FDG}$ as a positron emitter. Images were evaluated on a dedicated workstation. Semiquantitative parameters of $\left[{ }^{18} \mathrm{~F}\right]-F D G$ uptake and morphological, volumetric and densitometric parameters before and after contrast administration were analysed. Results were correlated with the histological and follow-up findings.

Results. Twenty-six SPNs were malignant and 30 were benign. Malignant lesions at both PET/CT and histology had a mean diameter of $1.8 \pm 1.2 \mathrm{~cm}$, a volume doubling time (DT) of 222 days, a mean standardized uptake value (SUV) of 4.7 versus 1.08 in benign lesions and a mean postcontrast enhancement of 44.8 $\mathrm{HU}$ as opposed to $4.8 \mathrm{HU}$ in benign nodules. Malignant lesions had a significantly shorter doubling time and significantly greater postcontrast enhancement compared with benign nodules. Based on the SUV and using a cut-off value of $>2.5$, PET/CT had a sensitivity of $76.9 \%$, specificity of $100 \%$, diagnostic accuracy of $89.2 \%$, positive predictive value (PPV) of $100 \%$ and negative predictive value (NPV) of $83.3 \%$. Based on doubling time (cut off $<400$ days), it had a sensitivity of $76.9 \%$, specificity of $93.3 \%$, accuracy of $85.7 \%$, PPV of $90.9 \%$ and NPV of $82.3 \%$. Based on postcontrast enhancement (cut off $>15 \mathrm{HU}$ ), it had a sensitivity of $92.3 \%$, specificity of $100 \%$, accuracy of $96.4 \%$, PPV of $100 \%$ and NPV of $93.7 \%$.

Conclusion. PET/CT allows accurate analysis of

anatomical/morphological and metabolic/functional correlations of SPN, providing useful data for identifying and locating the disease, for differentiating between malignant and benign nodules and for establishing the aggressiveness and degree of vascularity of pulmonary lesions. Therefore, partly in view of the
\end{abstract}

\author{
Riassunto \\ Obiettivo. Effettuare un'analisi delle informazioni complementari \\ sia morfologiche sia funzionali ottenibili mediante l'impiego \\ contestuale della ${ }^{18}$ F-FDG-PET e della TC multistrato (TCms) \\ con MdC nella caratterizzazione di noduli polmonari solitari \\ precedentemente classificati come indeterminati (NPSi). \\ Materiali e metodi. Sono stati valutati, mediante PET/TC \\ Discovery ST 16 slice GE (Medical Systems) con MdC organo- \\ iodato non ionico 56 pazienti con NPSi. Il radiotracciante \\ utilizzato è stato il ${ }^{18}$ F-FDG. Le immagini sono state valutate su \\ work-station dedicata con programma di elaborazione \\ volumetrica ed analizzati i parametri semiquantitativi dell'uptake \\ dell'FDG ed i dati morfologici, volumetrici e densitometrici prima \\ e dopo MdC alla TC. I risultati ottenuti sono stati confrontati con \\ l'esame istologico e il follow-up. \\ Risultati. Ventisei lesioni sono risultate maligne e 30 benigne. Le \\ lesioni maligne, sia alla PET/TCms che all'esame istologico, \\ hanno presentato diametro medio di $1,8 \pm 1,2 \mathrm{~cm}$, tempo di \\ duplicazione volumetrica (TD) di 222 giorni, uno Standardized \\ Uptake Value (SUV) medio di 4,7 (Av) versus 1,08 (Av) delle \\ lesioni benigne, aumento della densità media di 44,8 UH (mentre \\ in quelle di natura benigna il grado di potenziamento medio ̀̀ \\ risultato pari a 4,8 UH). Le lesioni polmonari maligne hanno \\ dimostrato un tempo di duplicazione significativamente più breve \\ ed un potenziamento post-contrastografico significativamente \\ maggiore se comparate con le nodularità benigne. Pertanto la \\ PET/TC, in base al SUV, utilizzando un cut-off superiore a 2,5, ha \\ riportato una sensibilità (Se) del 76,9\%, una specificità (Sp) del \\ $100 \%$, un'accuratezza diagnostica pari a $89,2 \%$ con un valore \\ predittivo positivo (VPP) del $100 \%$ ed un valore predittivo \\ negativo (VPN) pari a 83,3\%; in relazione al calcolo del TD (cut- \\ off<400 giorni) ha presentato una Se del 76,9\%, una Sp del \\ 93,3\%, una accuratezza del 85,7\%, con un VPP del 90,9\% e un \\ VPN del 82,3\%; in base al grado di potenziamento post- \\ contrastografico (cut-off>15 UH) ha evidenziato una Se del \\ 92,3\%, una Sp del 100\%, una accuratezza del 96,4\%, un VPP del \\ $100 \%$ e un VPN del 93,7\%. \\ Conclusioni. La PET-TC permette di effettuare una accurata \\ analisi delle correlazioni anatomo-morfologiche e metabolico- \\ funzionali del NPSi, consentendo di ottenere dati altamente
}


considerable reduction in time and cost of the single examinations, we believe that PET/CT will gain an increasingly dominant role in the diagnostic and therapeutic approach to lung cancer, especially in the preclinical phase.

Key words Lung nodule $\bullet$ Lung neoplasms diagnosis $\bullet$ CT $\bullet$ PET significativi in relazione alla evidenziazione e localizzazione del processo patologico, alla diagnosi differenziale tra nodulo polmonare maligno e benigno, al grado di aggressività della neoplasia e al grado di vascolarizzazione di una lesione polmonare. Pertanto, anche in considerazione della notevole riduzione dei tempi e dei costi complessivi dei singoli esami, possiamo ritenere che la PET-TCms con MdC organo-iodato, svolgerà un ruolo sempre più preponderante nel percorso diagnostico-terapeutico del cancro polmonare soprattutto in fase pre-clinica.

Parole chiave Nodulo polmonare - Diagnosi di neoplasia polmonare $\cdot T C \cdot P E T$

\section{Introduction}

The recent introduction of hybrid scanners such as those integrating positron emission tomography (PET) and multidetector computed tomography (MDCT) has enabled the simultaneous acquisition of anatomical, morphological and functional information, with 25\%-30\% faster imaging compared with the single examinations [1]. Moreover, it has improved sensitivity and specificity of oncological imaging [2-4].

A solitary pulmonary nodule (SPN) is defined as a round or oval lesion, with well-defined margins, up to $3 \mathrm{~cm}$ in size and completely surrounded by healthy pulmonary parenchyma [5]. An SPN is a relatively frequent finding in clinical practice, being detected in around $90 \%$ of cases as an incidental finding (preoperative imaging, imaging for heart disease or for other reasons), and may be due to a host of conditions ranging from benign granulomas to lung cancer [6]. Spiral computed tomography (MDCT) is superior to chest $\mathrm{X}$-ray in identifying indeterminate SPNs [7]. In large cohorts of patients at risk of lung cancer, SPN detection rate was $69 \%$ with MDCT [8] as opposed to $43 \%$ with single-slice spiral CT [7].

The malignancy rate of SPNs varies between $10 \%$ and $70 \%$ in the different series, so that diagnostic imaging avoids the use of more invasive and expensive procedures [9, 10]. In two thirds of these cases, both $\mathrm{CT}$ and chest radiography are unable to differentiate between benign and malignant lesions on the basis of calcifications or density features alone $[11,12]$. On the other hand, 5-year survival after resection of bronchogenic carcinoma ranges from $40 \%$ to $80 \%$ depending on the timeliness of diagnosis, so malignant lesions need to be identified early in order to promptly initiate appropriate treatment $[13,14]$.

The aim of our study was to analyse the additional morphological and functional information provided by the integration of $\left[{ }^{18} \mathrm{~F}\right]$-2-fluoro-2-deoxy-D-glucose (FDG)-PET with MDCT - with and without iv iodinated contrast material - in characterising SPNs (Fig. 1). The integrated PET/CT study allowed us to analyse indeterminate SPNs with diameters between $6 \mathrm{~mm}$ and $3 \mathrm{~cm}$, thereby considerably accelerating the diagnostic workup before biopsy and/or surgery.

\section{Introduzione}

Negli ultimi anni l'introduzione di apparecchiature ibride quali l'associazione tra la tomografia ad emissione di positroni (PET) e la tomografia computerizzata multistrato (TCms) ha consentito di ottenere informazioni anatomiche, morfologiche e funzionali contemporaneamente con una riduzione di circa il 25\%-30\% del tempo dei singoli esami [1]. È migliorata, inoltre, la sensibilità e la specificità diagnostica in campo oncologico [2-4].

Il nodulo polmonare solitario (NPS) è definito come una lesione rotondeggiante od ovalare, a margini definiti, di dimensioni inferiori o uguali a $3 \mathrm{~cm}$, completamente circondata da parenchima polmonare indenne [5]. IL NPS è una evenienza relativamente comune nella pratica clinica ed è presente in circa il $90 \%$ dei casi come riscontro occasionale (accertamenti pre-operatori, cardiopatie e per altri motivi) ed è dovuto ad una notevole varietà di alterazioni che vanno dai granulomi benigni al tumore polmonare [6]. La tomografia computerizzata con acquisizione volumetrica spirale (TCms) è superiore all'esame radiografico del torace nell'individuare il NPS indeterminato (NPSi) [7]. In ampie coorti di pazienti a rischio per carcinoma polmonare il riscontro del NPSi è stata del 69\% con TCms [8] rispetto al $43 \%$ della TC spirale a strato singolo [7].

La percentuale di malignità del NPS varia dal $10 \%$ al $70 \%$ nelle diverse casistiche e pertanto la diagnosi per immagini evita il ricorso a più invasive e costose procedure [9, 10]. In 2/3 di questi casi la TC e tanto meno l'esame Rx del torace non sono in grado di differenziare le lesioni benigne dalle maligne in rapporto alle sole caratteristiche delle calcificazioni o della densitometria [11, 12]. D’altro canto la sopravvivenza a 5 anni dopo la resezione del carcinoma broncogeno varia dal $40 \%$ all' $80 \%$ in relazione alla precocità della diagnosi, è pertanto importante identificare prontamente le lesioni maligne per attuare tempestivamente un trattamento appropriato [13, 14].

Lo scopo del nostro studio è stato quello di effettuare un'analisi delle informazioni complementari sia morfologiche sia funzionali, mediante l'impiego contestuale della $\left.{ }^{18} \mathrm{~F}\right]-F D G-P E T$ e della TC multistrato (TCms), eseguita anche con mezzo di contrasto $(M d C)$ organo-iodato per via venosa, nella caratterizzazione del NPSi (Fig. 1). Lo studio in- 

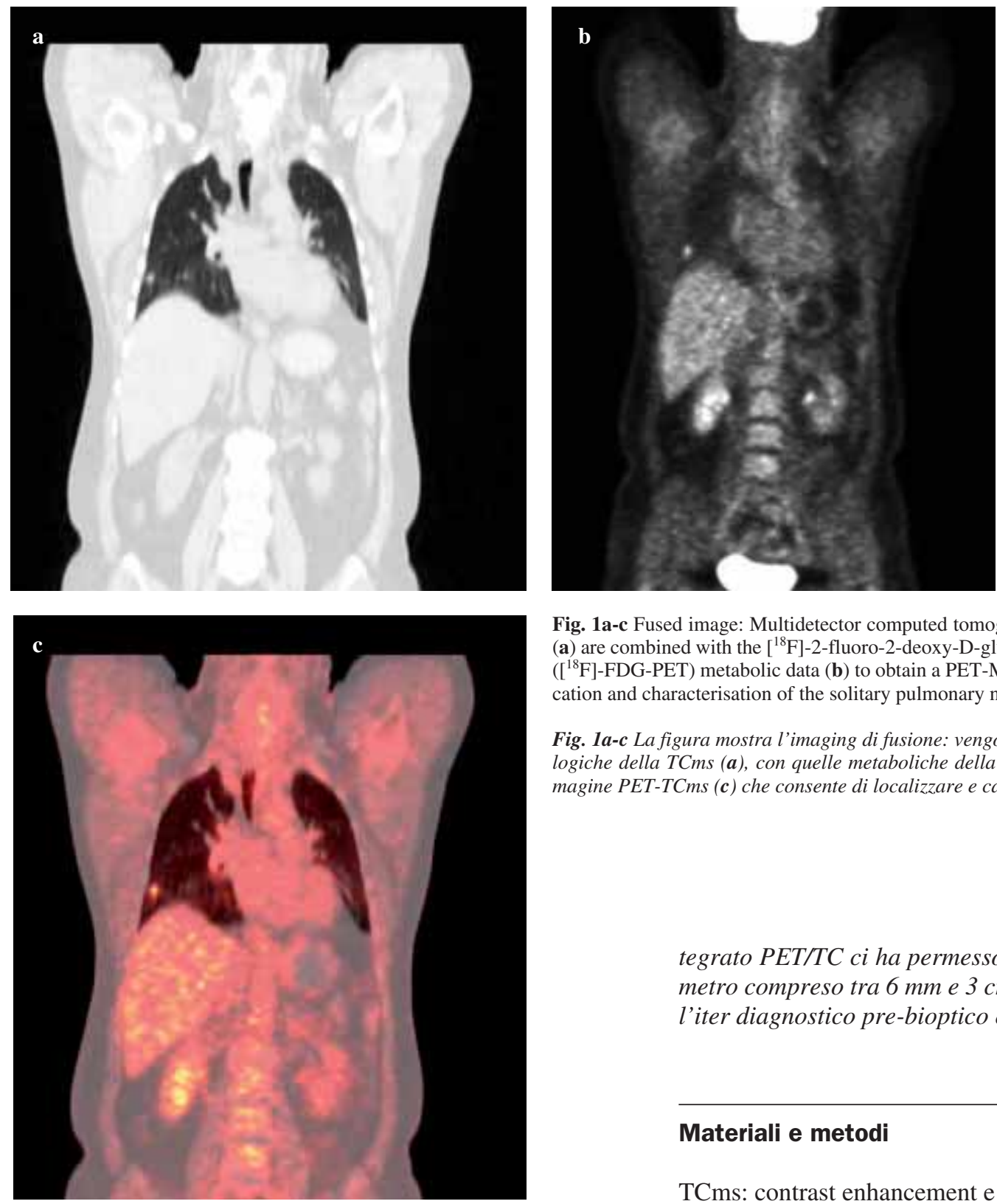

Fig. 1a-c Fused image: Multidetector computed tomography (MDCT) morphological data (a) are combined with the $\left[{ }^{18} \mathrm{~F}\right]$-2-fluoro-2-deoxy-D-glucose positron emission tomography $\left(\left[{ }^{18} \mathrm{~F}\right]-\mathrm{FDG}-\mathrm{PET}\right)$ metabolic data (b) to obtain a PET-MDCT fusion image (c), allowing location and characterisation of the solitary pulmonary node (SPN).

Fig. 1a-c La figura mostra l'imaging di fusione: vengono associate le informazioni morfologiche della TCms $(\boldsymbol{a})$, con quelle metaboliche della FDG-PET $(\boldsymbol{b})$ per ottenere una immagine PET-TCms (c) che consente di localizzare e caratterizzare un NPS.

\section{Materials and methods}

MDCT: contrast enhancement and doubling time (DT)

\section{Contrast enhancement}

The level of SPN enhancement after contrast administration has been assessed in a multicentric trial [15]. Lack of significant enhancement $\leq 15$ Hounsfield units (HU), predicts benign disease with a sensitivity of $98 \%$, a specificity of $58 \%$ and an accuracy of $77 \%$. This assessment was made on the basis of 3-mm-thick volumetric scans taken 1, 2, 3 and 4on (420 mg of iodine per kilogram of body weight, at a concentration of $300 \mathrm{mgI} / \mathrm{ml}$ and a flow rate of $3 \mathrm{ml} / \mathrm{s}$ ). Malignant lesions have stronger enhancement (38 HU on average) than benign lesions (10 $\mathrm{HU}$ on average). Inflammatory lesions al- tegrato PET/TC ci ha permesso di analizzare NPSi con diametro compreso tra $6 \mathrm{~mm} \mathrm{e} 3 \mathrm{~cm}$, accelerando notevolmente l'iter diagnostico pre-bioptico elo chirurgico.

\section{Materiali e metodi}

TCms: contrast enhancement e tempo di duplicazione (TD)

\section{Contrast enhancement}

Il valore dell'enhancement del NPS dopo somministrazione di mezzo di contrasto è stato stimato in un trial multicentrico [15]. L'assenza di un significativo enhancement, inferiore o uguale a 15 unità Hounsfield (UH) alla TC, è predittivo di benignità con una sensibilità del 98\%, una specificità del $58 \%$ ed un'accuratezza del $77 \%$. Tale valutazione è stata effettuata mediante l'acquisizione volumetrica a $3 \mathrm{~mm}$ di spessore al $1^{\circ}, 2^{\circ}, 3^{\circ}$ e $4^{\circ}$ minuto dopo l'inizio dell'iniezione di mezzo di contrasto organo-iodato nella quantità di $420 \mathrm{mg}$ di iodio per $\mathrm{Kg}$ di peso corporeo, concentrazione di 300 $\mathrm{mgI} / \mathrm{ml}$, con flusso di $3 \mathrm{ml} / \mathrm{s}$. Le lesioni maligne potenziano (in media $38 \mathrm{UH}$ ) più significativamente delle lesioni benigne (in media $10 \mathrm{UH}$ ). Anche le lesioni infiammatorie mostrano un elevato picco di enhancement (in media $40 \mathrm{UH}$ ) che, però, nel follow-up TC dopo trattamento medico (3-4 
so show marked peak enhancement (40 HU on average), but this is usually significantly reduced at follow-up CT after medical treatment (3-4 months), allowing their differentiation from malignant lesions, in which enhancement remains strong. The limitations of this method include false positive findings due to active inflammatory lesions, such as sarcoidosis or pulmonary tuberculosis, and false negative findings due to lesions smaller than $1 \mathrm{~cm}$ detected during the learning curve.

\section{Doubling time}

For most malignant nodules, volume doubling time (DT) is less than 400 days, with an average of 100 days in most cases $[16,17]$. Slower growth rates have been reported in elderly patients [18]. Benign nodules typically have a longer DT, and stability of an SPN on CT for 2 years implies a DT of at least 730 days and is generally considered a reliable indicator of benign disease [19].

When the diameter of a nodule increases by $26 \%$, its volume doubles. Manual measurement of the diameter of small lesions cannot therefore be considered accurate [20] and proves difficult on $\mathrm{CT}$ scans when the variations are less than $2 \mathrm{~mm}$. To overcome this limit, the growth rate of small nodules can be determined through serial measurements of volume rather than diameter. The error rates for manual measurements have been reported to be $10 \%$ for diameter and $38 \%$ for volume, as a result of partial volume effects, vascular geometry, motion artefacts, asymmetrical growth and poor reproducibility of manual measurements $[16,21]$. Specific image-analysis applications allow automatic segmentation of nodule contours after volumetric acquisition, threedimensional (3D) reconstruction of the nodule and precise calculation of volume. Automatic segmentation of lung nodules follows a specific image-analysis protocol.

Use of a 3D technique for volume determination involves obtaining contiguous high-resolution images of the entire nodule. Because small nodules are the main focus of volume assessment, it is important to achieve the highest possible resolution along the scan plane by using the smallest possible pitch.

In our study, we used specific software for SPN volume determination: Advanced Lung Analysis (ALA; General Electric Medical Systems). The analysis involves selecting the region of interest (ROI) containing the nodule, extrapolating images of the sections containing the ROI and sampling them as an isotropic space (resolution is identical in the three planes) to obtain a 3D reconstruction. The three measurements are made on this filtered and segmented image of the nodule and fulfil strict accuracy and repeatability criteria.

PET: standardised uptake value (SUV)

The problem of differential diagnosis of an SPN often starts with an incidental finding that cannot be characterised with noninvasive methods. Various studies have demonstrated the mesi), di solito si riduce significativamente permettendo la discriminazione con le lesioni maligne, in cui permane elevato. Le metodica presenta tuttavia dei limiti dovuti a reperti falsamente positivi in presenza di lesioni infiammatorie attive, quali la sarcoidosi o la tubercolosi polmonare, e reperti falsamente negativi per lesioni inferiori ad un centimetro durante la "learning curve".

Tempo di duplicazione (TD)

Il tempo di duplicazione del volume per la maggior parte dei noduli maligni è inferiore a 400 giorni ed è mediamente di circa 100 giorni nella maggior parte dei casi [16, 17]. Una crescita più lenta è stata riscontrata nei pazienti anziani [18]. Tipicamente i noduli benigni hanno un tempo di duplicazione più lungo e la stabilità del NPS all'esame TC per un periodo di 2 anni, implica un tempo di duplicazione di almeno 730 giorni ed è considerato generalmente un attendibile indicatore di benignità [19].

Quando diametro di un nodulo aumenta del $26 \%$ il suo volume raddoppia. Pertanto la misurazione manuale del diametro di piccole lesioni non può essere ritenuta accurata [20] ed è difficile da effettuare su scansioni TC per variazioni inferiori ai $2 \mathrm{~mm}$. Per superare questa limitazione la percentuale di crescita di noduli di piccole dimensioni può essere effettuata con una serie di misurazioni del volume piuttosto che del diametro. $\grave{E}$ stato anche valutato che la misurazione manuale nel nodulo può comportare un errore del $10 \%$ per quanto riguarda la valutazione del diametro e del $38 \%$ per quanto riguarda la valutazione del volume, dovuto all'effetto di volume parziale, alla geometria vascolare, ad artefatti da movimento, alla crescita asimmetrica ed alla difficile ripetibilità delle misurazioni manuali [16, 21]. Specifiche applicazioni nell'analisi delle immagini permettono una segmentazione automatica dei contorni del nodulo dopo un'acquisizione volumetrica, una ricostruzione $3 D$ del nodulo ed il preciso calcolo volumetrico. La segmentazione automatica dei noduli polmonari segue uno specifico protocollo di analisi delle immagini.

L'uso di una tecnica tridimensionale (3D) per la determinazione del volume nodulare richiede immagini contigue ad alta risoluzione dell'intero nodulo. Poiché l'obiettivo di una valutazione volumetrica è focalizzata su noduli piccoli, è importante ottenere la maggiore risoluzione possibile lungo l'asse di scansione usando il pitch più piccolo possibile.

Nel nostro studio, per la valutazione volumetrica del NPS, abbiamo utilizzato uno specifico software: Advanced Lung Analysis (ALA, General Electric Medical Systems) con il quale, per effettuare l'analisi, viene selezionata la regione d'interesse contenente il nodulo; le immagini delle sezioni contenenti la regione di interesse sono quindi estrapolate e campionate come uno spazio isotropico (la risoluzione è identica nelle tre dimensioni) per ottenere una ricostruzione 3D. Le tre misurazioni dimensionali sono fatte su questa immagine del nodulo filtrata e segmentata e risponde a severi criteri di accuratezza e ripetibilità. 
value of PET in differential diagnosis between benign and malignant pulmonary nodules. Particularly important in this respect is the uptake value of the lesion, which is calculated on the basis of a semiquantitative, nondimensional parameter known as standardised uptake value (SUV) and expressed through the following formula:

$$
\mathrm{SUV}=\frac{\text { radioactivity }(\mathrm{kBq}) \div \text { tissue volume }(\mathrm{ml})}{\text { injected dose }(\mathrm{kBq}) \div \text { body weight }(\mathrm{g})}
$$

This value expresses the ratio between the amount of radiotracer taken up by a given lesion and the amount of radiotracer that would hypothetically be present in a region of equal volume if the tracer were uniformly distributed throughout the body. In particular, it is accepted that an SUV $\leq 2.5$ is highly predictive of benign disease, whereas a value $>2.5$ is highly predictive of malignancy (sensitivity $92 \%-94 \%$, specificity $83 \%-90 \%)$ [22, 23]. It should, however, be recalled that PET with $\left[{ }^{18} \mathrm{~F}\right]$-FDG yields false negative results in approximately $50 \%$ of patients with bronchioloalveolar carcinoma, a relatively rare disease accounting for less than $2 \%$ of all lung cancers [24], and in patients with carcinoid.

\section{Patients}

Fifty-six patients ( 36 men, 20 women; mean age 63 years) with indeterminate SPN were reexamined with FDG-PET and contrast-enhanced MDCT performed in a single session. In particular, we evaluated DT and postcontrast density changes on MDCT and metabolic features on PET to characterise the SPN. All patients had already undergone CT scans at our department for different indications, and each was found to have a solitary nodule in the lung parenchyma. We therefore retrospectively reviewed these baseline examinations. PET/MDCT was carried out 1-3 months after the baseline CT scan (mean 45 days). Ten patients had a history of pulmonary or extrapulmonary NOM0 or NOMX cancer that had been resected in all cases.

\section{Patient selection}

We considered nodules discovered incidentally at chest radiography performed for other reasons (cough, dyspnoea, chest pain, routine preoperative X-ray, etc.) and those identified during $\mathrm{CT}$ for the evaluation of patients with previously excised pulmonary or extrapulmonary primary cancer. Inclusion criteria were:

- Single solid mass smaller than $3 \mathrm{~cm}$

- Round or oval shape

- No unequivocal signs of benign or malignant disease

- Normally ventilated peripheral parenchyma

- Absence of hilar or mediastinal node enlargement at baseline CT

- No extrathoracic findings suggestive of distant metastasis at baseline $\mathrm{CT}$
PET: standardised uptake value (SUV)

La problematica relativa alla diagnosi differenziale del nodulo polmonare solitario inizia spesso con un rilievo occasionale che spesso non trova una soluzione definitiva mediante metodiche non invasive. Vari studi documentano la validità della metodica PET nella diagnosi differenziale fra nodulo polmonare benigno e maligno. Particolare importanza riveste in questo senso il valore di uptake della lesione calcolato mediante un dato semiquantitativo, adimensionale definito "Standardised Uptake Value" (SUV) ed espresso dalla seguente formula:

$$
S U V=\frac{\text { radioattività }(k B q) \div \text { volume tessuto }(m l)}{\text { dose iniettata }(k B q) \div \text { peso corporeo }(g)}
$$

Questo valore esprime il rapporto fra quantità di tracciante accumulata in una certa lesione e quantità di tracciante che sarebbe ipoteticamente presente in una regione di ugual volume se il tracciante fosse distribuito omogeneamente in tutto il corpo. In particolare è accettato che un valore di SUV inferiore o uguale a 2,5 è altamente predittivo di benignità della lesione, mentre un valore superiore a 2,5 è altamente predittivo di malignità (sensibilità 92\%-94\%, specificità 83\%-90\%) [22, 23]. È tuttavia opportuno ricordare che la $P E T$ con 2-fluoro-2deossi-D-glucosio $\left(\left[{ }^{18} F\right]-F D G\right)$ è falsamente negativa in circa il $50 \%$ dei pazienti con carcinoma bronchiolo-alveolare, una patologia neoplastica piuttosto rara, che rappresenta meno del $2 \%$ di tutti i tumori polmonari [24] e nei pazienti con carcinoide.

\section{Pazienti}

Sono stati esaminati 56 pazienti (36 maschi, 20 femmine, età media 63 anni) con NPS precedentemente classificato come indeterminato (NPSi) e rivalutati con esame FDG-PET e TCms con MdC organoiodato effettuati contestualmente. Sono stati valutati in particolare il tempo di duplicazione e le modificazioni densitometriche dopo MdC alla TCms ed il dato metabolico PET, al fine di caratterizzare il NPS. I pazienti da noi analizzati avevano precedentemente eseguito presso il nostro Dipartimento un esame TC per vari ordini di motivi, a conclusione del quale era stata individuata in ciascuno di essi una nodularità solitaria nel contesto del parenchima polmonare; è stata quindi da noi effettuata una valutazione retrospettiva di tale esame. L'indagine PET/TCms è stata eseguita a distanza variabile da 1 a 3 mesi rispetto al precedente controllo TC (in media 45 giorni). In 10 pazienti risultava una storia clinica di neoplasia polmonare o extrapolmonare NOMO o NOMX già sottoposta ad exeresi chirurgica.

Selezione dei pazienti

Sono stati presi in considerazione sia noduli scoperti incidentalmente ad un precedente esame radiografico del torace eseguito per altro motivo (tosse, dispnea, dolore toracico, 
- N0M0 nodule in previously resected pulmonary neoplasm

- MOMX nodule in previously resected extrathoracic neoplasm

Exclusion criteria were:

- Multiple pulmonary nodules

- Unequivocal signs of benign disease (exclusion of fatcontaining nodules or calcifications)

- Unequivocal signs of malignant disease (nodules $>3 \mathrm{~cm}$ or with irregular margins and blurred contours)

- Associated atelectasis

- Presence of hilar or mediastinal node enlargement at baseline CT

- Pulmonary neoplasms with extrathoracic findings suggestive of distant metastasis at baseline CT

- M1 extrathoracic neoplasms.

Nodules showing nonsignificant tracer uptake at PET that were stable at follow-up CT and measured $2 \mathrm{~cm}$ and $3 \mathrm{~cm}$ were studied by invasive procedures for histological characterisation (CT- or bronchoscopy-guided biopsy, video-assisted thoracoscopic biopsy). Nodules showing no tracer uptake, smaller than $2 \mathrm{~cm}$, and stable at follow-up CT were considered benign and were not characterised histologically but were followed up at intervals of 3-6 months depending on size. Nodules showing significant tracer uptake (SUV >2.5) were referred for pulmonary resection (nodulectomy, lobectomy) regardless of the $\mathrm{CT}$ findings.

\section{PET/MDCT examination technique}

All examinations were performed using a Discovery ST integrated PET/MDCT system (GE, General Electric, Medical Systems). This system combines a High-Speed Ultra 16-detector-row (912 detectors per row) CT unit and a PET scanner with 10080 bismuth germanate (BGO) crystals in 24 rings. Patients were instructed to fast for at least $6 \mathrm{~h}$, as glucose competes with $\left[{ }^{18} \mathrm{~F}\right]-\mathrm{FDG}$ for cellular uptake. Serum glucose levels were checked before administering $\left[{ }^{18} \mathrm{~F}\right]-$ FDG, and the radiotracer was only injected if blood glucose levels were normal to avoid the diagnostic potential of PET being reduced by the competitive effect of high blood glucose. Patients with hyperglycaemia were invited to take a short walk to increase muscle activity and lower blood glucose to below $150 \mathrm{mg} / \mathrm{dl}$. A dose of $370 \mathrm{MBq}$ of radiotracer was administered intravenously as a single bolus 45-60 min before the examination. During this phase, adequate hydration was maintained with an intravenous infusion of saline (250-500 ml) to reduce pooling of the tracer in the renal system. At the same time, about $900 \mathrm{cc}$ of a contrast-containing solution was administered orally to obtain adequate opacification of the intestinal loops according to the protocol followed by our department.

For the examination, patients were placed supine in the gantry with their arms above their head. The examination started with a scanogram. A low-amperage $(80 \mathrm{~mA})$ nonenhanced CT scan was then acquired to correct attenuation for the PET study, using the following parameters: $140 \mathrm{kV}$ (the highest kilovolt value) to obtain good quality images through the hips and shoulders; $80 \mathrm{~mA}$; large field of view (FOV) (420-500 mm); CT slice thickness $3.75 \mathrm{~mm}$ (reconstructed routine pre-operatoria, ecc.), che noduli individuati nel corso di una valutazione TC in pazienti con neoplasia primitiva a sede polmonare o extrapolmonare già trattata chirurgicamente. I criteri d'inclusione delle nodularità sono di seguito riportati:

- singola formazione solida con dimensioni inferiori ai $3 \mathrm{~cm}$;

- morfologia sferica o ovalare;

- assenza di chiare caratteristiche deponenti per benignità o malignità;

- parenchima periferico normoareato;

- assenza di linoadenopatie ilo-mediastiniche alla prima indagine TC;

- assenza di reperti extratoracici sospetti o indicativi di metastasi a distanza alla prima indagine TC;

- nodularità in pregressa neoplasia polmonare operata NOMO;

- nodularità in neoplasia extratoracica operata MO o MX. I criteri di esclusione sono i seguenti:

- multiple nodularità polmonari;

- chiare caratteristiche deponenti per benignità (esclusione di nodularità contenenti grasso o calcificazioni);

- chiare caratteristiche deponenti per malignità (noduli>3 cm o con margini irregolari e limiti sfumati);

- atelettasia associata;

- presenza di linfoadenopatie ilo-mediastiniche alla prima indagine TC;

- neoplasie polmonari con reperti extratoracici sospetti o indicativi di metastasi a distanza alla prima indagine TC;

- neoplasie extratoraciche M1.

I pazienti portatori di noduli non captanti significativamente all'esame PET, stabili al follow-up TC e di dimensioni tra 2 e $3 \mathrm{~cm}$ sono stati comunque sottoposti a procedure invasive per la tipizzazione istologica (biopsia TC guidata o broncoscopica, escissione videotoracoscopica). I NPSi non captanti, di dimensioni inferiori ai $2 \mathrm{~cm}$, se stabili al followup TC sono stati considerati benigni e non tipizzati istologicamente, ma invitati a proseguire ulteriormente i controlli di diagnostica per immagini ad intervalli di 3-6 mesi in relazione alle dimensioni. I pazienti portatori di noduli captanti significativamente all'esame PET (SUV>2,5) sono stati indirizzati in chirurgia, indipendentemente dal risultato TC per la successiva resezione polmonare (nodulectomia, lobectomia).

\section{Tecnica di esecuzione dell'esame PET/TCms}

Tutti gli esami sono stati eseguiti con un sistema scanner integrato PET/TCms Discovery ST (GE, General Electric, Medical Systems). Tale sistema combina uno scanner TC modello High Speed Ultra con 16 file di detettori (912 detettori per fila) con un tomografo PET con 10080 cristalli di germanato di bismuto (BGO) disposti in 24 anelli. Il paziente è stato tenuto digiuno da almeno 6 ore, poiché il glucosio compete con il $\left[^{18} \mathrm{~F}\right]-F D G$ per la captazione cellulare. Prima dell'iniezione del $\left[{ }^{18} F\right]-F D G$ si è provveduto alla valutazione della glicemia, iniettando il radiofarmaco solo in condizioni di normoglicemia per evitare di ridurre il potenziale diagnostico della PET per l'effetto competitivo dovuto ad elevati livelli glicemici. Nel caso di iperglicemia si è invitato il paziente a incrementare temporaneamente l'attività mu- 
at $1.25 \mathrm{~mm}$ ) to approximate the width of the PET section; reconstructed section interval of $3.27 \mathrm{~mm}$ to coincide with the PET section intervals; no intravenous administration of contrast material; scan speed less than $1 \mathrm{~s}$ per rotation to minimise motion artefacts; axial scan coverage (length of the patient being studied) to include all of the PET sections to be corrected; acquisition of the entire CT volume during a single breath-hold to obtain a more faithful reproduction of the anatomical conditions of PET.

After nonenhanced CT, the PET study was done with the two-dimensional (2D) technique in the caudocranial direction from the proximal third of the femur to the skull; six to seven beds were acquired (each bed duration was 4 minutes). Images were reconstructed using a standard iterative algorithm [ordered subsets expectation maximisation (OSEM)], for a mean PET examination time of 24-28 min. Immediately after the PET study, contrast-enhanced CT was carried out with iv administration of nonionic iodinated contrast material (100-120 ml, $370 \mathrm{mgI} / \mathrm{ml}, 420 \mathrm{mgI} / \mathrm{kg}$ at $3 \mathrm{ml} / \mathrm{s})$, obtaining two successive stacks of scans: the first comprised the upper abdomen with a delay of $30 \mathrm{~s}$ from the injection onset; the second extended from the neck to the pelvis with a 60- to 80 -s delay. Following these acquisitions, a further stack of scans can be used to characterise equivocal hepatorenal lesions. Finally, after having the patients lower their arms along the trunk, axial scans of the skull were acquired.

The acquisition technique was $120-140 \mathrm{kV}$, automatic milliamperage (limit 330-350 mA), thickness $3.750 \mathrm{~mm}$ (reconstructed at $1.25 \mathrm{~mm}$ ), acquisition mode 27.50/1.375:1, gantry rotation time $0.6 \mathrm{~s}$, large FOV, matrix $512 \times 512$. Total duration of the PET/CT study was $40 \mathrm{~min}$ on average.

\section{Image analysis}

Images were reconstructed on an Advantage-Windows 4.2 workstation (GE, General Electric, Medical Systems), with PET/CT fusion imaging software and automatic segmentation software (ALA). ALA allows the size, shape and density of pulmonary nodules to be correctly assessed by selecting the ROI and performing a three-dimensional (3D) segmentation with elimination of adjacent structures. For the semiquantitative analysis of $\left[{ }^{18} \mathrm{~F}\right]-\mathrm{FDG}$ uptake, the SUV was established and normalised for $\left[{ }^{18} \mathrm{~F}\right]-\mathrm{FDG}$ uptake in an ROI in relation to total injected dose and body weight. Square ROIs were manually placed on the axial tomograms in correspondence with the visible margins of the lesion in an area of abnormal FDG uptake, considering the area of greatest uptake as the lesion centre. In patients not showing $\left[{ }^{18} \mathrm{~F}\right]$-FDG uptake, the ROI was extrapolated from the axial chest CT tomograms by placing it at the nodule equator and setting the window level to parenchyma. The size of the ROIs was proportional to the area of increased uptake identified visually or to the area of low-uptake corresponding to the nodule identified on axial CT only. Morphological and volumetric assessment was done with ALA reconstruction software. This automatic segmentation protocol allowed us to determine volume changes of a nodule by retrospectively comparing the tomographic data of the PET/CT acquisition with a previous CT or PET/CT scan (Figs. 2, 3). Data of all the scolare mediante una breve "passeggiata" per riportare la glicemia almeno sotto i $150 \mathrm{mg} / \mathrm{dl}$. Il radiofarmaco, nella dose di $370 \mathrm{MBq}$, è stato somministrato per via endovenosa in bolo unico 45-60 min prima dell'inizio dell'esame. Durante questa fase si è provveduto ad una adeguata idratazione mediante infusione endovena di soluzione fisiologica (250-500 $\mathrm{ml}$ ) per ridurre il ristagno di tracciante nell'emuntorio renale. Contemporaneamente sono stati somministrati per via orale circa 900 cc di una soluzione contenente $\mathrm{MdC}$ per una adeguata opacizzazione delle anse intestinali secondo il protocollo praticato nel nostro Dipartimento.

Per l'esecuzione dell'esame, il paziente viene posizionato in decubito supino con le braccia sopra la testa all'interno del gantry e l'indagine inizia con uno scanogramma. Viene quindi acquisita una TC basale a basso amperaggio (80 mA) necessaria per la correzione dell'attenuazione per lo studio PET, utilizzando i seguenti parametri:

- $140 k V$ (il valore $k V$ più alto) per ottenere immagini di buona qualità attraverso le anche e le spalle;

- 80mA;

- campo visivo di grandi dimensioni (420-500 mm);

- spessore della sezione TC pari a 3,75mm (retroricostruibile a 1,25 $\mathrm{mm}$ ) per approssimare la larghezza della sezione PET;

- intervallo tra le sezioni ricostruito pari a $3,27 \mathrm{~mm}$, in modo che coincida con la spaziatura tra le sezioni PET;

- non viene somministrato alcun contrasto per via venosa;

- velocità di scansione inferiore a 1 secondo per rivoluzione, in modo da ridurre al minimo gli artefatti da movimento:

- la copertura della scansione assiale (lunghezza del Paziente sottoposto a scansione) dovrà includere tutte le sezioni PET da correggere;

- acquisizione dell'intero volume TC durante sospensione respiratoria, per riprodurre in modo più simile le condizioni anatomiche della PET.

Terminata la TC, viene effettuato l'esame PET con tecnica $2 D$ in direzione caudo-craniale a partire dal III prossimale dei femori a comprendere il cranio; si acquisiscono 6-7 lettini (durata 4 min ognuno). Le immagini sono state ricostruite utilizzando un algoritmo iterativo standard (OSEM: Ordered Subsets Expectation Maximization), per una durata dell'indagine PET in media pari a 24-28 minuti circa. Subito dopo l'acquisizione PET viene effettuato l'esame TC dopo somministrazione di MdC organo-iodato non ionico endovena (100-120 ml, $370 \mathrm{mgI} / \mathrm{ml}, 420 \mathrm{mgI} / \mathrm{kg}$ a $3 \mathrm{ml} / \mathrm{s}$ ), predisponendo due pacchetti susseguenti di scansioni: il primo comprendente l'addome superiore con un ritardo di 30 s rispetto all'inizio dell'iniezione del $\mathrm{MdC}$, il secondo esteso dal collo fino alla pelvi con un ritardo di 60-80 s. Al termine di queste acquisizioni, se necessario, viene impostato un nuovo pacchetto di scansioni per caratterizzare lesioni dubbie epato-renali. Infine, dopo avere fatto addurre lungo il tronco gli arti superiori, si acquisiscono scansioni assiali sul cranio.

La tecnica di acquisizione è stata: 120-140 kV, amperaggio automatico (limite 330-350 mA), spessore di 3,750 mm (retroricostruibile a $1,25 \mathrm{~mm}$ ), modalità di acquisizione 27,50/1,375:1, velocità di rotazione del gantry di 0,6 s, campo di vista di grandi dimensioni, matrice $512 \times 512$. La dura- 

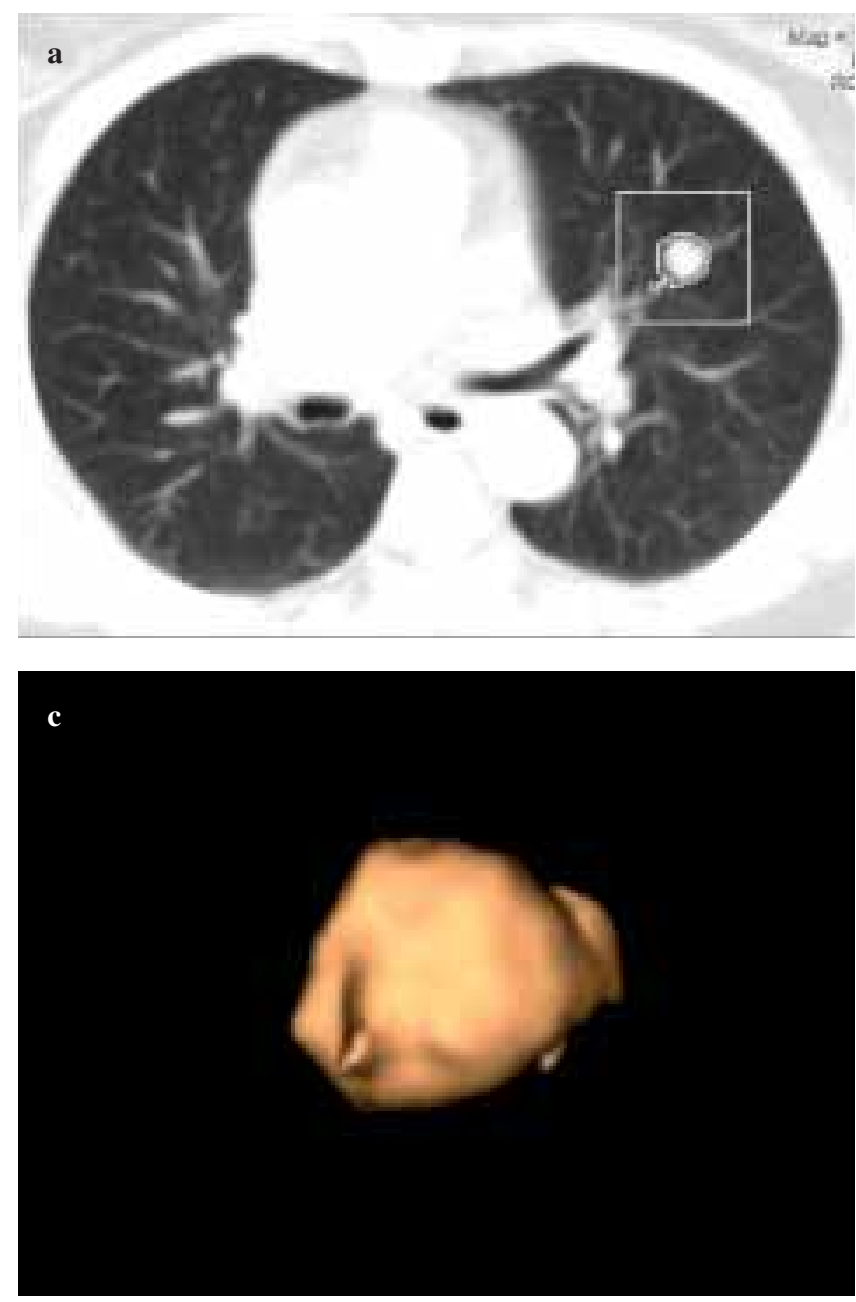

$\mathbf{e}$



CT examinations evaluated were reprocessed and reconstructed according to the ALA software instructions: 1.25$\mathrm{mm}$ slice thickness, 3.27-mm interval to ensure correspondence with the spacing of the PET sections, and bone filter, applied to the nonenhanced acquisition. In addition, changes in nodule density between the nonenhanced and contrast-enhanced CT scan after the emission scan were quantified to


Fig. 2a-e Pulmonary carcinoma: example of the segmentation of computed tomography (CT) images and application of the three-dimensional (3D) ALA postprocessing software (a). Solitary pulmonary nodule (SPN) showing a volume of $4.979 \mathrm{~cm}^{3}$, corresponding to a $36 \%$ dimensional increase in 68 days (b), when compared with the previous findings $\left(3.660 \mathrm{~cm}^{3}\right)(\mathbf{c})$. The calculated doubling time (DT) is 154 days, suggesting a neoplasm. The fused positron emission tomography (PET)/CT image (d) locates with extreme precision the area of metabolic hyperactivity at site of the pulmonary nodule with a standardised uptake value (SUV) $>2.5(\mathbf{e})$.

Fig. 2a-e Ca polmonare. a Esempio di segmentazione delle immagini TC ed applicazione del software di ricostruzione $3 D$ ALA. $\boldsymbol{b}$ NPS con volume di $4,979 \mathrm{~cm}^{3}$ che rappresenta un incremento dimensionale del $36 \%$, in 68 giorni, rispetto alla precedente indagine (c) in cui il volume del nodulo era $3,660 \mathrm{~cm}^{3}$. Il dato è indicativo di un tempo di duplicazione di 154 giorni sospetto per patologia eteroplasica.d L'immagine PET-TC di fusione localizza con estrema precisione l'area di iperattività metabolica in corrispondenza del nodulo polmonare con un $S U V>2,5$ rispetto alla immagine $F D G$ $\operatorname{PET}(\boldsymbol{e})$.

ta complessiva dell'intera acquisizione PET/TC è risultata in media di circa $40 \mathrm{~min}$.

\section{Analisi delle immagini}

Le immagini sono state rielaborate su una "workstation" Advantage-Windows 4.2 (GE, General Electric, Medical Sy- 

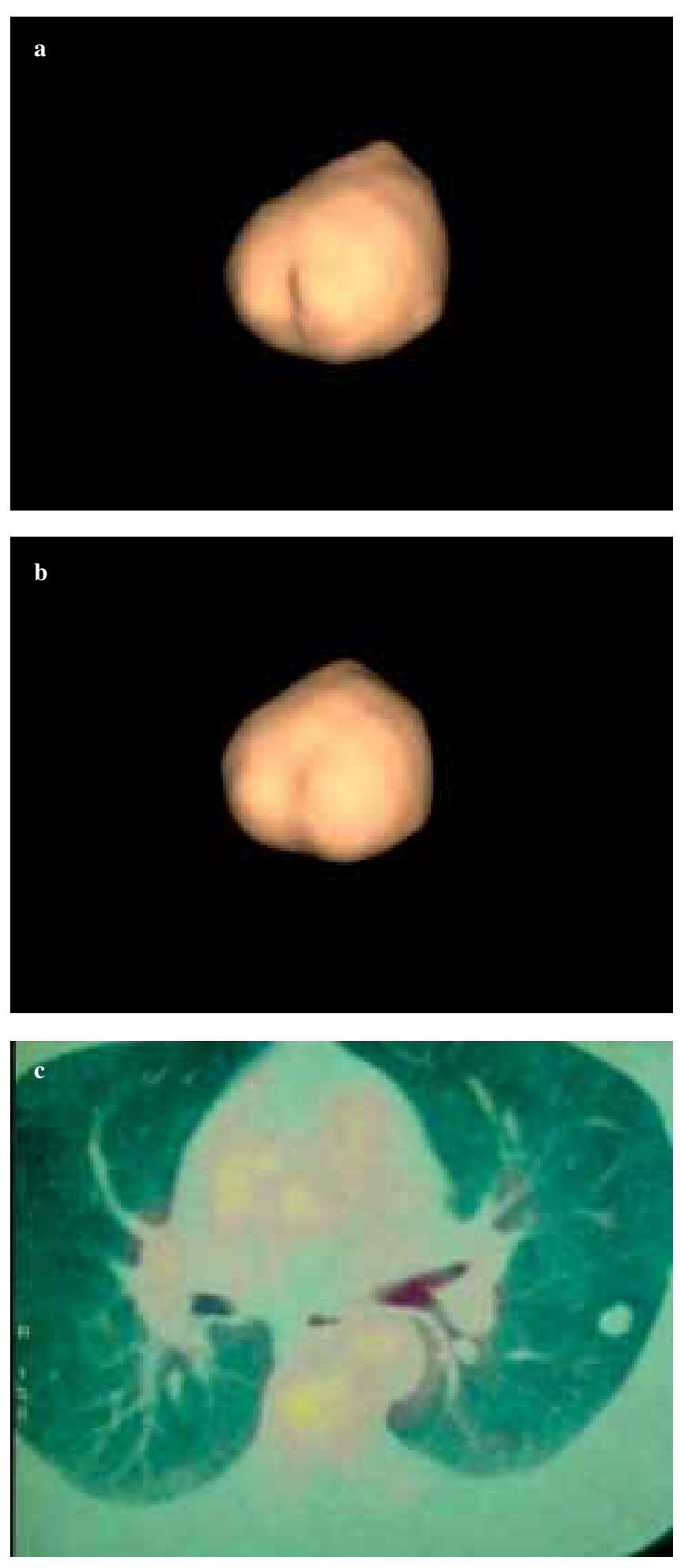

Fig. 3a-c Benign nodule: volumetric evaluation of the solitary pulmonary nodule (SPN) demonstrated the stability of the nodule after 126 days. Threedimensional (3D) reconstruction of an SPN using the ALA software on 2 May $2005\left(2.067 \mathrm{~cm}^{3}\right)$ (a) and on 5 September $2005\left(1.688 \mathrm{~cm}^{3}\right)(\mathbf{b})$. The fused positron emission tomography computed tomography (PET/CT) image does not show metabolic activity at the site of the nodule (c).

Fig. 3a-c Nodulo benigno. La valutazione volumetrica del NPS ha mostrato la stabilità del nodulo che in 126 giorni non ha modificato il suo volume. Ricostruzione $3 D$ mediante software ALA di NPS (a) il 2/5/2005 (2,067 $\left.\mathrm{cm}^{3}\right)$ e $\boldsymbol{b}$ il 5/9/2005 (1,688 $\left.\mathrm{cm}^{3}\right)$. c L'immagine di fusione PET-TC non mostra attività metabolica a livello del nodulo.
Table 1 Threshold values for density changes (contrast enhancement), Doubling time (DT) and standardised uptake value (SUV) in the differential diagnosis between benign and malignant lesions

\begin{tabular}{lll}
\hline & $\begin{array}{l}\text { Probable } \\
\text { benignancy }\end{array}$ & $\begin{array}{l}\text { Probable } \\
\text { malignancy }\end{array}$ \\
\hline Density change postcontrast & $\leq 15 \mathrm{HU}$ & $>15 \mathrm{HU}$ \\
Doubling Time & $>465$ days & $<400$ days \\
Standardised Uptake Value & $\leq 2.5$ & $>2.5$ \\
\hline
\end{tabular}

Tabella 1 Valori soglia delle modificazioni densitometriche (contrast enhancement), del tempo di duplicazione (TD) e del Standardised Uptake Value $(S U V)$ considerati differenziali tra lesioni benigne e maligne

\begin{tabular}{lll}
\hline & $\begin{array}{l}\text { Probabile } \\
\text { benignità }\end{array}$ & $\begin{array}{l}\text { Probabile } \\
\text { malignità }\end{array}$ \\
\hline $\begin{array}{l}\text { Modificazioni densitometriche } \\
\text { dopo MdC }\end{array}$ & $\leq 15 \mathrm{UH}$ & $>15 \mathrm{UH}$ \\
$\begin{array}{l}\text { Tempo di duplicazione } \\
\text { Standardised Uptake Value }\end{array}$ & $>465$ giorni & $<400$ giorni \\
\hline
\end{tabular}

stems) mediante ricostruzioni con software di fusione PET$T C$ e software di segmentazione automatica (ALA) che permette, selezionando la regione di interesse ed effettuando una segmentazione tridimensionale con eliminazione delle strutture adiacenti, di ottenere una corretta valutazione di dimensioni, forma e densitometria dei noduli polmonari. Per l'analisi semiquantitativa dell'uptake del $\left[{ }^{18} \mathrm{~F}\right]-F D G$, il Valore di Uptake Standardizzato (SUV) è stato stabilito e normalizzato per l'accumulo del $\left[{ }^{18} \mathrm{~F}\right]-F D G$ in una regione di interesse (ROI) sulla dose totale iniettata e sul peso corporeo del paziente. Sono state manualmente definite delle ROI quadrangolari sui tomogrammi assiali, in corrispondenza dei margini visibili della lesione in un'area di anomalo accumulo di FDG, considerando l'area di maggior uptake come il centro della lesione. Nei pazienti nei quali non si evidenziava una iperfissazione del $\left[{ }^{18} \mathrm{~F}\right] \mathrm{FDG}$ all'esame PET, la ROI ̀̀ stata estrapolata essenzialmente dai tomogrammi assiali della scansione TC del torace posizionandola a livello dell'equatore del nodulo identificato settando la finestra per il parenchima. Le dimensioni delle ROI utilizzate è stata proporzionale all'area di elevata captazione identificata visivamente o della nodularità ipocaptante documentata esclusivamente nelle immagini assiali TC. La valutazione morfologico-volumetrica è stata effettuata mediante software di ricostruzione ALA. Tale protocollo di segmentazione automatica ha permesso di calcolare le modificazioni volumetriche della stessa lesione nodulare comparando retrospettivamente i dati tomografici dell' acquisizione PET-TC con un precedente esame TC o PET/TC (Figg. 2, 3). I dati di acquisizione di tutti gli esami TC da noi valutati sono stati rielaborati e retroricostruiti in accordo con le indicazioni del software ALA: spessore delle slices pari a 1,25 mm, intervallo tra le slices di 3,27 mm in modo che coincida con la spaziatura tra 


\section{Correlation between max SUV and enhancement Correlazione tra SUV max e potenziamento post-contrastografico}

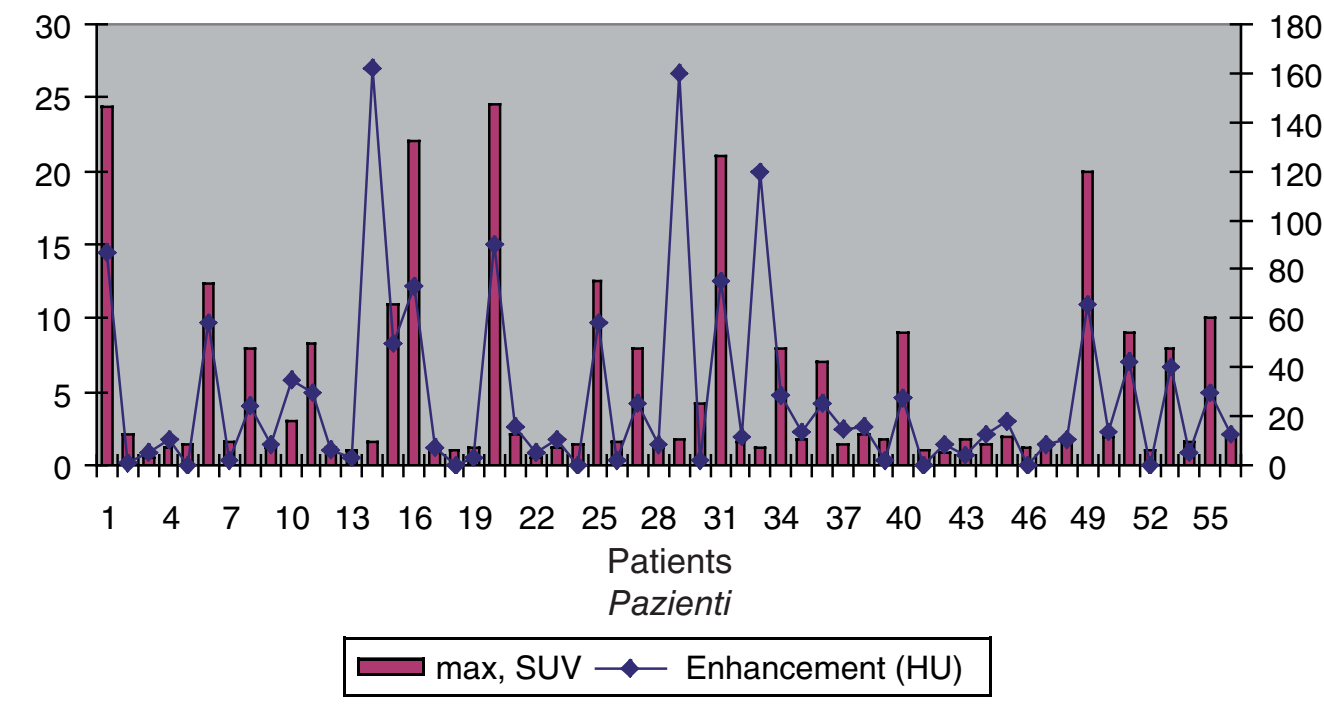

Table 2 Relationship between maximum Uptake Value (SUV) and contrast enhancement at the sice of the nodule. Contrast enhancement is defined as the difference between the pre- and post-contrastgraphic densitometric value. SUV appears being directly proportional to contrast enanchment.

Tabella 2 Sono riportati i risultati relativi al valore del dato semiquantitativo (SUV max) calcolato a livello delle lesioni nodulari ed il corrispettivo grado di potenziamento post-contrastografico espresso come differenza tra la densità basale ed il valore densitometrico dopo somministrazione di MdC organo-iodato. È evidente la proporzionalità diretta tra i due dati per cui ad un valore di SUV elevato corrisponde un significativo potenziamento post-contrastografico.

determine the significance of lesion enhancement. This assessment was made by placing a circular ROI with an estimation area equal to $605-70 \%$ of the nodule surface on the equatorial tomogram.

The cut-off points used to differentiate between benign and malignant lesions are reported in Table 1. The results obtained were subsequently compared with the histopathological or follow-up data to identify statistically significant correlations.

\section{Results}

Of the 56 nodules analysed, 26 were malignant (18 carcinomas, two carcinoids, six metastases), 30 were benign (ten granulomas, six hamartomas, four nonspecific fibroses) and ten were not characterised but were considered benign (lesions showing no uptake at PET, with a maximum diameter smaller than $2 \mathrm{~cm}$ and stable at follow-up CT).

The mean diameter of malignant lesions was $1.8 \pm 1.2 \mathrm{~cm}$, whereas that of benign lesions was $2 \pm 1 \mathrm{~cm}$. Mean volume DT of malignant lesions was 222 days. Mean SUV of malignant lesions was 4.7 versus 1.08 of benign lesions. Malignant lesions had a mean enhancement after contrast administration of $44.8 \mathrm{HU}$ as opposed to $4.8 \mathrm{HU}$ in benign lesions. No le sezioni PET e filtro per osso ("bone") applicati all'acquisizione basale. Sono state inoltre quantificate le modificazioni densitometriche del nodulo tra l'esame TC basale e l'esame TC dopo MdC acquisito successivamente alla scansione emissiva, onde stimare la significatività o meno del grado di potenziamento della lesione. Tale valutazione è stata attuata mediante la definizione di una ROI circolare con un'area di stima pari al 60\%-70\% della superficie del nodulo a livello del tomogramma medio-equatoriale.

I cut-off considerati differenziali tra lesioni benigne e maligne, utilizzati nel nostro studio, sono riportati nella Tabella 1 . I risultati ottenuti sono stati successivamente confrontati per individuare eventuali correlazioni statisticamente significative, con i dati istopatologici o del follow-up.

\section{Risultati}

Dallo studio dei 56 pazienti analizzati sono emersi i seguenti risultati. Ventisei sono risultate le lesioni polmonari maligne (18 carcinomi, 2 carcinoidi, 6 metastasi). Trenta lesioni benigne: 10 granulomi, 6 amartomi, 4 esiti fibrotici aspecifici e 10 lesioni non tipizzate considerate benigne (diametro max sotto ai $2 \mathrm{~cm}$, non captanti all'esame PET e stabili al follow-up TC).

Il diametro medio dei noduli maligni è stato di 1,8 $1,2 \mathrm{~cm}$. 

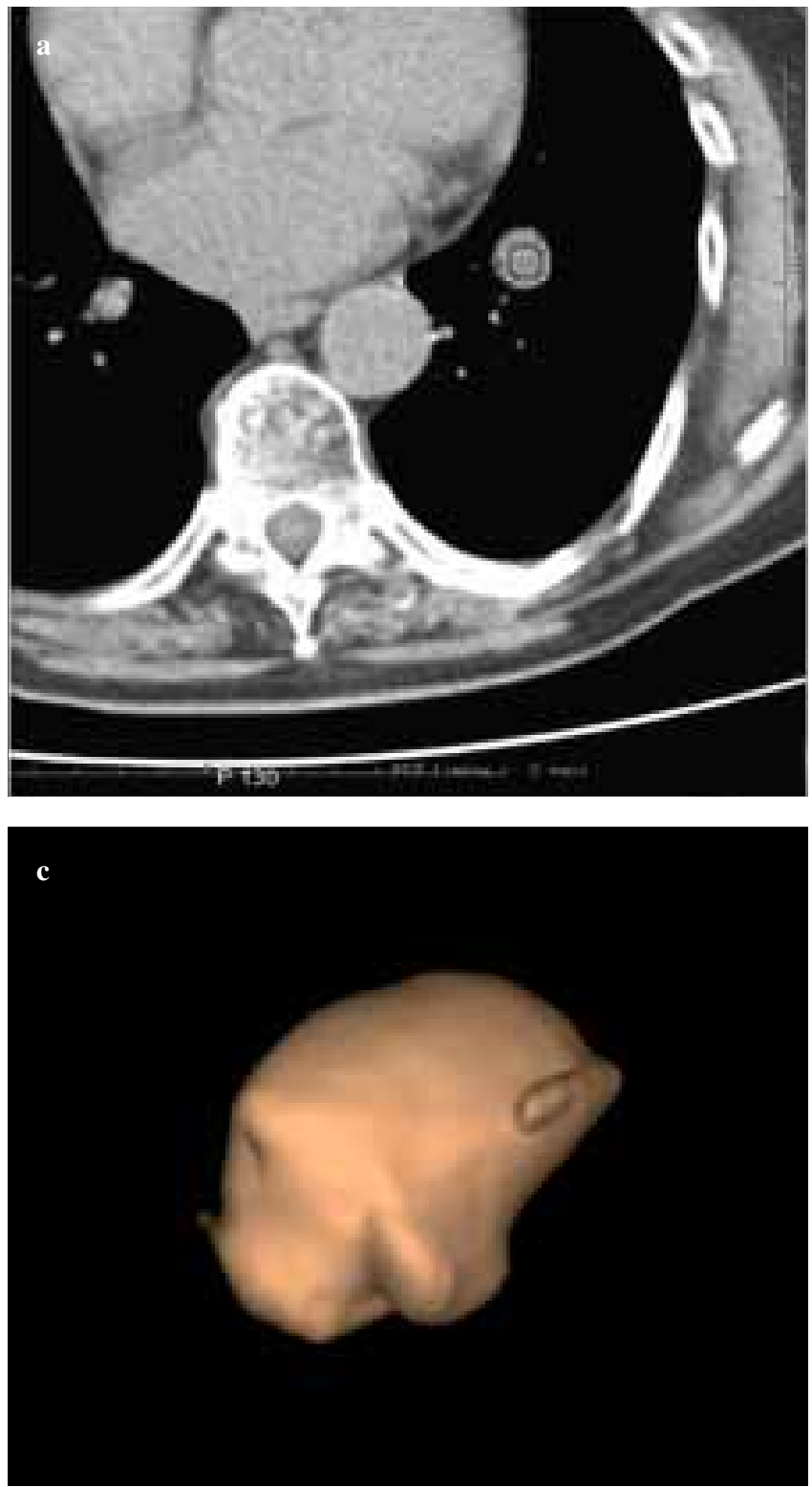

significant differences were found between the mean dimensions of benign and malignant lesions. Malignant lesions had a significantly shorter DT and significantly greater enhancement $(p<0.001)$ compared with benign nodules (Table 2). In malignant nodules, a significant correlation was found between SUV and DT $(r=-0.89, p=0.0001)$ and SUV and enhancement $(r=0.32 ; p=0.001)$. No significant correlations were identified for benign lesions.

FDG uptake, using a SUV $>2.5$ as a significance threshold, correctly characterised 20/26 malignancies. Only two nodules $(2.3 \mathrm{~cm}$ and $2.4 \mathrm{~cm})$ with SUVs of 1.6 and 1.8 and a DT just over 400 days but with strong enhancement after contrast administration ( $>15 \mathrm{HU}$ ) were characterised by histology and classified as pulmonary carcinoids (Fig. 4). The four other lesions, subsequently characterised as well-differentiated squamous-cell carcinomas, had a maximum SUV of 2.1, and only two had almost significant enhancement levels (16 HU and $18 \mathrm{HU}$ ) and a DT just under 400 days. Because

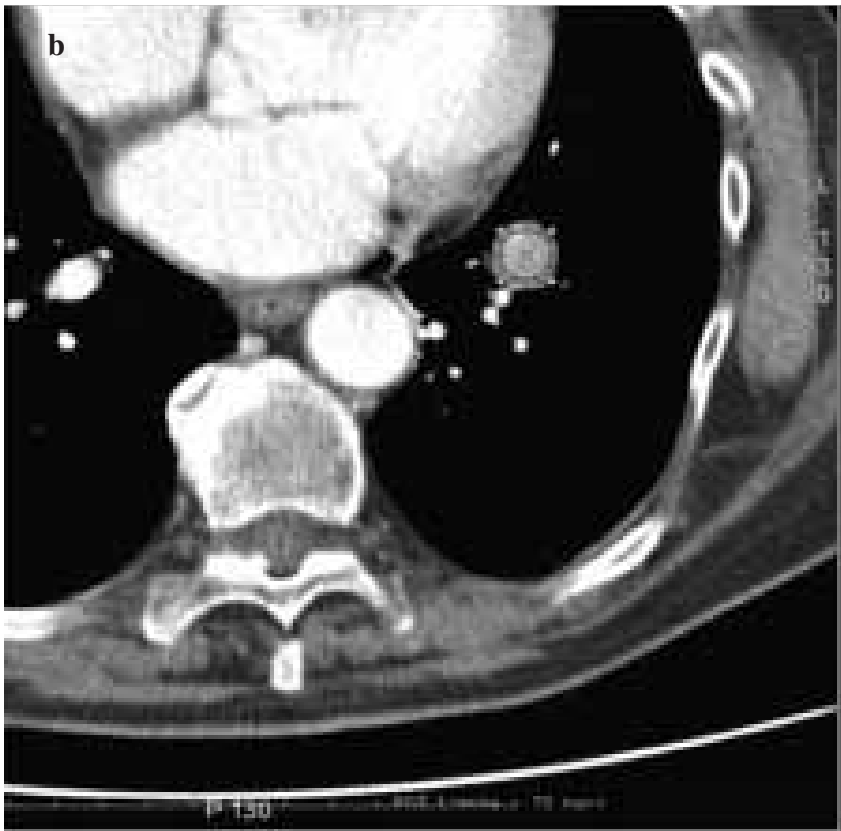

Fig. 4a-c Pulmonary carcinoid: A significant density increase is observed when comparing the pre- $(34 \mathrm{HU})$ (a) and postcontrastographic computed tomography (CT) (196 HU) (b) examinations. Conversely, the semiquantitative parameter standardised uptake value (SUV) does not show any significant increase $(\mathrm{SUV}=2)$. The volume calculated by the ALA software shows a perfect correlation with the surgical findings (c).

Fig. 4a-c Carcinoide polmonare. Si rileva un significativo incremento della densità rispetto alla TC basale (34 UH) (a) rispetto a quella dopo MdC (196 UH) (b). Il parametro semiquantitativo del SUV non è invece risultato significativamente aumentato $(S U V=2)$. Il volume calcolato mediante ALA ̀̀ stato perfettamente corrispondente con il reperto chirurgico $(\boldsymbol{c})$.

Il diametro medio dei noduli benigni è stato di $2 \pm 1 \mathrm{~cm}$. Il tempo medio di duplicazione volumetrica delle lesioni maligne è stato di 222 giorni. Il valore medio del SUV delle lesioni maligne è risultato pari a 4,7 (Av) versus 1,08 (Av) delle lesioni benigne. Le nodularità polmonari maligne hanno presentato un potenziamento post-contrastografico medio pari a 44,8 UH, mentre in quelle di natura benigna il grado di potenziamento medio è risultato pari a 4,8 UH. Non sono state individuate significative differenze tra le dimensioni medie dei noduli benigni e maligni. Le lesioni polmonari maligne hanno dimostrato un tempo di duplicazione significativamente più breve ed un potenziamento post-contrastografico significativamente maggiore $(p<0,001)$ comparate con le nodularità benigne (Tabella 2). Nelle nodularità maligne è stata individuata una significativa correlazione tra il SUV ed il tempo di duplicazione ( $r=-0,89, p=0,0001)$ e tra il SUV ed il grado di potenziamento post-contrastografico $(r=0,32$; $p=0,001)$. Al contrario non sono state individuate significa- 
Table 3 Diagnostic reliability of positron emission tomography/computed tomography (PET/CT) in relation to doubling time (DT), contrast enhancement and standardised uptake value (SUV) in the differential diagnosis between benign and malignant lesions

\begin{tabular}{|c|c|c|c|}
\hline & $\begin{array}{l}\text { DT }<400 \\
\text { days } \%\end{array}$ & $\mathrm{HU}>15 \%$ & SUV $>2.5 \%$ \\
\hline Sensitivity & 76.9 & 92.3 & 76.9 \\
\hline Specificity & 93.3 & 100 & 100 \\
\hline $\begin{array}{l}\text { Positive predictive } \\
\text { value (PPV) }\end{array}$ & 90.9 & 100 & 100 \\
\hline $\begin{array}{l}\text { Negative predictive } \\
\text { value (NPV) }\end{array}$ & 82.3 & 93.7 & 83.3 \\
\hline Accuracy & 85.7 & 96.4 & 89.2 \\
\hline
\end{tabular}

Tabella 3 Attendibilità diagnostica della PET/TC in relazione al TD, al potenziamento post-contrastografico e al SUV nel differenziare le nodularità benigne dalle maligne

\begin{tabular}{|c|c|c|c|}
\hline & $\begin{array}{l}T D<400 \\
\text { giorni }(\%)\end{array}$ & $U H>15(\%)$ & $S U V>2,5(\%)$ \\
\hline Sensibilità & 76,9 & 92,3 & 76,9 \\
\hline Specificità & 93,3 & 100,0 & 100,0 \\
\hline $\begin{array}{l}\text { Valore predittivo } \\
\text { positivo }(V P P)\end{array}$ & 90,9 & 100,0 & 100,0 \\
\hline $\begin{array}{l}\text { Valore predittivo } \\
\text { negativo }(V P N)\end{array}$ & 82,3 & 93,7 & 83,3 \\
\hline Accuratezza & 85,7 & 96,4 & 89,2 \\
\hline
\end{tabular}

of their relatively high SUV and their size (greater than 2 $\mathrm{cm}$ ), these four lesions underwent surgical excision.

On the basis of SUV and DT, PET/CT yielded 20 true positives and six false negatives, whereas on the basis of degree of enhancement (Hounsfield units), it yielded 24 true positive and two false negative results. Therefore, based on the SUV with a cut-off value of 2.5 and histological correlation, PET/CT had a sensitivity of $76.9 \%$, specificity of $100 \%$, diagnostic accuracy of $89.2 \%$, positive predictive value (PPV) of $100 \%$ and negative predictive value (NPV) of $83.3 \%$. Based on DT (cut-off $<400$ days), it had a sensitivity of $76.9 \%$, specificity of $93.3 \%$, accuracy of $85.7 \%$, PPV of $90.9 \%$ and NPV of $82.3 \%$. Based on the degree of enhancement after contrast administration (cut-off $>15 \mathrm{HU}$ ), it had a sensitivity of $92.3 \%$, specificity of $100 \%$, diagnostic accuracy of $96.4 \%$, PPV of $100 \%$ and NPV of $93.7 \%$ (Table 3). Overall, PET/TC had a high diagnostic accuracy, with sensitivity and specificity of $92.3 \%$ and $100 \%$, respectively.

\section{Discussion}

The natural history of a malignant pulmonary nodule is characterised by progressive exponential growth, and this was supported by the observation that DT remain constant in $80 \%-90 \%$ of tumours considered in our study. Instead, be- tive correlazioni nei casi di lesioni benigne.

L'uptake del FDG, utilizzando come soglia di significatività un valore di $S U V>2,5$, ha correttamente caratterizzato 20/26 neoplasie maligne; 2 sole lesioni polmonari (dimensioni 2,3 cm e 2,4 cm) che presentavano un SUV di 1,6 e 1,8, un TD di poco superiore ai 400 giorni, ma un importante potenziamento post-contrastografico $(>15 \mathrm{UH})$, sono state tipizzate istologicamente e classificate come carcinoidi polmonari (Fig. 4). Le altre quattro lesioni, successivamente tipizzate come carcinomi squamocellulari ben differenziati, hanno presentato un valore di SUV max di 2,1 , due solamente presentavano un potenziamento ai limiti della significatività (16 e $18 \mathrm{UH}$ ) ed un TD di poco inferiore ai 400 giorni. Le quattro lesioni, per il relativo incremento del SUV e le loro dimensioni (superiori ai $2 \mathrm{~cm}$ ), sono state comunque sottoposte a resezione chirurgica. Quindi in base ai parametri SUV e TD, la PET/TC ha presentato 20 veri positivi e 6 falsi negativi; in relazione al dato contrastografico $(U H)$ invece, 24 veri positivi e 2 falsi negativi.

Pertanto la PET/TC, in base allo Standardised Uptake Value (SUV), utilizzando un cut-off superiore a 2,5 e confrontandolo con il reperto istologico, ha riportato una sensibilità (Se) del 76,9\%, una specificità (Sp) del 100\%, un'accuratezza diagnostica pari a 89,2\% con un valore predittivo positivo (VPP) del $100 \%$ ed un valore predittivo negativo (VPN) pari a 83,3\%; in relazione al calcolo del TD (cutoff $<400$ giorni) ha presentato una Se del 76,9\%, una Sp del 93,3\%, una accuratezza del 85,7\%, con un VPP del 90,9\% e un VPN del 82,3\%; in base al grado di potenziamento postcontrastografico (cut-off $>15 \mathrm{UH}$ ) ha evidenziato una Se del $92,3 \%$, una Sp del 100\%, una accuratezza del 96,4\%, un VPP del 100\% e un VPN del 93,7\% (Tabella 3). Complessivamente la PET-TC ha mostrato una elevata accuratezza diagnostica con Se e Sp rispettivamente del 92,3\% e 100\%.

\section{Discussione}

La storia naturale del nodulo polmonare maligno è caratterizzata da una crescita progressiva ed esponenziale, supportata dall'osservazione che i tempi di duplicazione rimangono costanti dall' $80 \%$ al $90 \%$ dei tumori valutati. Al contrario le lesioni polmonari benigne crescono molto lentamente con tempi di duplicazione significativamente più lunghi dei tumori maligni. L'assenza di crescita in un nodulo polmonare sopra $i 2$ anni suggerisce la benignità ed implica un tempo di duplicazione maggiore dei 700 giorni [12, 19]. I risultati del nostro studio indicano un tempo di duplicazione volumetrica superiore ai 400 giorni per le 30 nodularità benigne versus 222 giorni in media per le 26 lesioni maligne. Tale dato è in accordo con quanto dimostrato da altri autori $[25,26] i$ quali hanno rilevato come la maggior parte dei noduli polmonari benigni hanno tempi di duplicazione superiori ai 465 giorni mentre le lesioni maligne usualmente presentano tempi di duplicazione inferiori ai 400 giorni.

Il potenziale ritardo nella diagnosi e nel trattamento del cancro polmonare e la relativa efficacia e sicurezza delle attuali tecniche di diagnostica invasiva sconsigliano un approccio legato all'utilizzo di indagini di tipo grossolano nel- 
nign lesions grow very slowly, with significantly longer DT. The lack of growth of a pulmonary nodule over 2 years suggests benign disease and implies a DT greater than 700 days $[12,19]$. The results of our study indicate a DT greater than 400 days for the 30 benign nodules as opposed to 222 days on average for the 26 malignant lesions. This finding is in agreement with previous studies [25, 26], which found that the majority of benign nodules have DT greater than 465 days, whereas malignant lesions have DT less than 400 days.

The risk of delay in the diagnosis and treatment of lung cancer and the relative efficacy and safety of invasive modern diagnostic techniques do not support approaches relying on rough assessments of the morphovolumetric changes of nodules and make 2D calculations, even done with an accurate CT scan, poorly reliable. The ability of modern MDCT scanners to provide very high spatial resolution $(1.25 \mathrm{~mm})$ images, even with very fast focused scans of the ROI $(10 \mathrm{~cm}$ of lung parenchyma in less than $2 \mathrm{~s}$ ) and the availability of highly accurate and repeatable 3D volume reconstructions (ALA) allow assessment of volume changes in subcentimetre nodules even in close follow-up (45 days on average in our study with a minimum interval of 30 days).

Malignant cells exhibit increased glucose metabolism and uncontrolled growth. Following the first report [27], other authors confirmed that cancer cells have increased activity of the key enzymes of glycolysis [28]. The concurrent increase in glucose uptake by the cells can be measured by PET with FDG, a glucose analogue. $\left[{ }^{18} \mathrm{~F}\right]$-deoxyglucose enters the cell through a facilitated transport mechanism, undergoes phosphorylation by hexokinase and becomes trapped intracellularly. Because the metabolism of phosphorylated FDG is extremely slow, the amount present in the cell is directly related to glycolytic rate. As a result, FDG-PET measures the increased glucose metabolism typical of malignant cells in vivo. Many experimental and clinical studies have demonstrated a significant increase in FDG uptake in all types of lung tumours [29-31]. Glucose metabolism measured by FDGPET correlated in our study with the DT of pulmonary malignancies: cell uptake of FDG-PET and DT were found to be inversely correlated.

High levels of glucose metabolism are associated with shorter DT. Previous reports have confirmed the relationship existing between glucose metabolism measured by FDG-PET and growth rate in different types of tumour. A study of 23 patients with primary cerebral tumour was the first to establish a link between the glycolytic activity measured by FDG-PET and tumour growth in vivo. It postulated that a progressive increase in glucose metabolism accompanies the transition from slow to rapid growth in poorly differentiated tumours [32].

Another study of 13 patients with head and neck tumours examined the relationship between glucose metabolism measured by FDG-PET and proliferative activity assessed with DNA flow cytometry. In some cell types, glucose metabolism measured by FDG-PET varied proportionately to tumour growth [33]. These experiences and our results demonstrate that even indeterminate pulmonary nodules may be differentiated on the basis of volume doubling and that DT is inversely proportional to glucose metabolism. In malignant la valutazione delle modificazioni morfo-volumetriche delle nodularità, e rendono scarsamente attendibile un calcolo bidimensionale eseguito anche con un accurato esame TC. La possibilità di eseguire con le attuali apparecchiature TC multistrato una valutazione ad altissima risoluzione spaziale $(1,25 \mathrm{~mm})$, in tempi brevissimi un'acquisizione anche "focalizzata" sulla regione di interesse (scansione di $10 \mathrm{~cm}$ circa di parenchima polmonare in meno di 2 s), e la disponibilità di software di ricostruzione volumetrica $3 D$ (ALA) dotato di elevata accuratezza e ripetibilità, permettono di valutare le modificazioni volumetriche di nodularità subcentimetriche anche in ristretti follow-up (45 giorni in media nel nostro studio con intervallo temporale minimo di 30 giorni).

Le cellule dei tumori maligni mostrano un incrementato metabolismo del glucosio ed una crescita incontrollata. Fin dalla descrizione originale [27], altri autori hanno verificato come le cellule cancerose presentino un incremento nell'attività degli enzimi chiave della glicolisi [28]. Il concomitante aumento dell'uptake cellulare del glucosio può essere misurato usando la PET con il FDG un analogo del glucosio. Il ${ }^{18} \mathrm{~F}$-desossiglucosio entra nella cellula con un meccanismo di trasporto facilitato, viene fosforilato dall'esochinasi e quindi bloccato intracellularmente. Poiché il metabolismo del FDG-fosforilato è estremamente lento, la quantità presente all'interno della cellula correla direttamente con il flusso glicolitico. Perciò la FDG-PET misura l'aumentato metabolismo del glucosio caratteristico delle cellule maligne in vivo. In molti studi sperimentali e clinici, un significativo incremento nell'uptake del FDG è stato dimostrato in tutti i tipi di tumore polmonare [29-31]. Il metabolismo del glucosio misurato dalla FDG-PET correla nel nostro studio con il tempo di duplicazione delle lesioni polmonari maligne: l'uptake cellulare della FDG-PET ed il tempo di duplicazione è risultato inversamente correlato.

Alti livelli del metabolismo del glucosio sono associati con un più breve tempo di duplicazione. Studi precedenti hanno confermato la relazione esistente tra il metabolismo del glucosio misurato con la FDG-PET e la percentuale di crescita in differenti tipi di tumore. In uno studio su 23 pazienti con tumore cerebrale primitivo, per la prima volta, è stato stabilito il legame tra l'attività glicolitica misurata con la FDG-PET e la percentuale di crescita dei tumori in vivo. Fu postulato che un progressivo incremento nel metabolismo del glucosio accompagna la trasformazione da una lenta ad una rapida crescita nei tumori scarsamente differenziati [32].

In un altro studio su 13 pazienti con neoplasie maligne della regione della testa e del collo è stata esaminata la relazione esistente tra il metabolismo del glucosio misurato con la FDG-PET e l'attività proliferativa valutata attraverso studi di flusso-citometria del DNA. In alcuni tipi cellulari, il metabolismo del glucosio misurato con la FDG-PET varia proporzionalmente con la crescita tumorale [33]. In base a tali esperienze ed al risultato del nostro studio è possibile stabilire che anche le lesioni nodulari polmonari di natura indeterminata possono essere differenziate in base al raddoppio volumetrico e che il tempo di duplicazione è inversamente proporzionale al metabolismo del glucosio. Per le lesioni maligne il tempo di duplicazione correla con il metabolismo del glucosio misurato con la FDG-PET. Nella nostra coorte di pazienti abbiamo osservato una relazione di- 

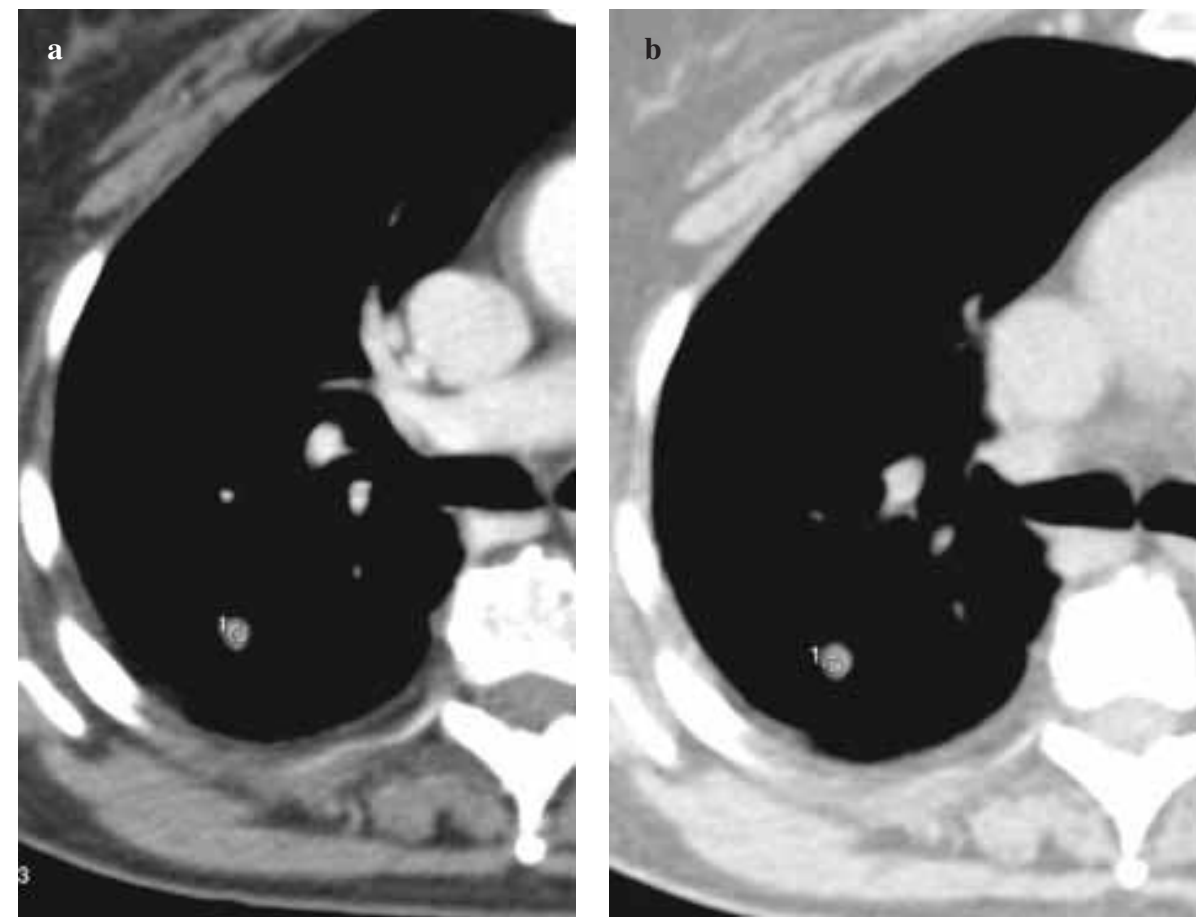

Fig. 5a-c Pulmonary carcinoma. A direct relationship exists between the densiometric increase doserved at the site of the SPN after c.m. administration (56 HU) (a), compared to the basal CT examination (10 UH) (b), and the corresponding semiquantitative SUV data (12.4) at èETCT (c).

Fig. 5a-c Ca polmonare. Esiste una diretta correlazione tra l'aumento della densità del NPS alla TC con MdC (56 UH) (a) rispetto a quella della TC in condizioni basali (10 UH) (b) ed il dato semiquantitativo del SUV (12,4) alla PET-TC (c). lesions, DT is correlated with glucose metabolism as measured by FDG-PET. In our patients, we observed a direct relationship between tumour growth assessed with 3D volume measurement and FDG uptake in lung cancer (Fig. 5). Moreover, there is a clear difference between degree of the vascularity of benign and malignant nodules. This difference may provide a further opportunity for distinguishing benign and malignant nodules using radiological imaging. Taking an enhancement value greater than $15 \mathrm{HU}$ as an index of malignancy, we calculated a sensitivity and specificity of $98 \%$ and retta tra la crescita tumorale valutata mediante calcolo percentuale volumetrico $3 D$ e l'uptake di FDG nel cancro polmonare (Fig. 5). C'è anche una distinta differenza tra la vascolarizzazione dei noduli benigni e quelli maligni. Questa differenza può offrire una ulteriore opportunità nel distinguere noduli polmonari benigni e maligni usando la tecnologia dell'imaging radiologico. Usando un enhancement superiore alle 15 UH come indice di malignità è stata calcolata una sensibilità ed una specificità pari a $98 \%$ e $58 \%$, rispettivamente, un'accuratezza del $77 \%$ e un VPP e un VPN del 68\% e del $96 \%$ [15]. Dopo iniezione di MdC il tempo di transito medio nell'albero vascolare polmonare è di circa 30 $s$, il tempo medio necessario per raggiungere la massima attenuazione è di 120 s, i cambiamenti nei primi 120 s sono clinicamente i più importanti [34]. Nel nostro studio la valutazione post-contrastografica dei noduli è stata eseguita effettuando l'acquisizione sul torace in media dopo 60-70 s rispetto all'inizio dell'infusione del contrasto, allo scopo di ottenere una curva tempo-attenuazione diagnostica. Il metabolismo di un tumore maligno dipende dalla sua neovascolarizzazione che fornisce ossigeno e glucosio in quantità sufficiente a permettere la crescita tumorale. C'è una significa- 
$58 \%$ respectively, accuracy of $77 \%$ and PPV and NPV of $68 \%$ and $96 \%$, respectively [15]. Mean transit time through the pulmonary vasculature after contrast injection is around $30 \mathrm{~s}$, mean time required to reach peak enhancement is $120 \mathrm{~s}$ and changes during the first $120 \mathrm{~s}$ are clinically the most relevant [34]. In our study, the evaluation of nodules after contrast administration was made by performing the chest scan 60-70 s after the beginning of the injection to obtain a diagnostic time-enhancement curve. The metabolism of malignant tumours depends on their neovascularisation, which provides enough oxygen and glucose to ensure tumour growth. A significant correlation exists between the mean vascular density of lung tumours, peak enhancement on CT and uptake on $\left[{ }^{18} \mathrm{~F}\right]-F D G-P E T ~[35]$. There is a close correlation between DT that indicates the growth rate of lung tumours, the degree of enhancement that is related to tumour vascularity, and $\left[{ }^{18} \mathrm{~F}\right]-\mathrm{FDG}$ concentration [36].

Based on the SUV, with a cut-off point of 2.5 and compared with histology, PET/CT had a sensitivity of $76.9 \%$, specificity of $100 \%$, diagnostic accuracy of $89.2 \%$, PPV of $100 \%$ and NPV of $83.3 \%$. Based on the DT (cut-off $<400$ days), it had a sensitivity of $76.9 \%$, specificity of $93.3 \%$, accuracy of $85.7 \%$, PPV of $90.9 \%$ and of $82.3 \%$. Based on the degree of contrast enhancement (cut-off $\geq 15 \mathrm{HU}$ ), it had a sensitivity of $92.3 \%$, specificity of $100 \%$, accuracy of $96.4 \%$, PPV of $100 \%$ and NPV of $93.7 \%$. These values confirm the increasing ability of the combined simultaneous use of contrast-enhanced MDCT and $\left[{ }^{18} \mathrm{~F}\right]-\mathrm{FDG}-\mathrm{PET}$ to substantially improve the analysis of indeterminate SPNs, differentiating benign and malignant lesions with a PPV of $91 \%-100 \%$ and a NPV of $83 \%-93 \%$. Overall sensitivity and specificity of PET/CT were $92.3 \%$ and $100 \%$, respectively. These data do, however, require validation by larger studies.

One limitation of our study concerns mean nodule size, which was relatively high $(1.8 \pm 1.2 \mathrm{~cm}$ for malignant lesions and $2 \pm 1 \mathrm{~cm}$ for benign ones) and may have facilitated detection of the parameters considered. It is, however, possible to predict that the technological evolution of PET scanners, with smaller detectors, will permit recognition and metabolic characterisation of smaller nodules with similar or better accuracy. Another limitation is that our series contained no cases of nonsolid or subsolid nodules, but we need to consider that the incidence of tumours with these characteristics is low.

\section{Conclusion}

In conclusion, our study confirms that PET/CT permits accurate analysis of anatomical/morphological and metabolic/ functional correlations in indeterminate SPNs, providing data that are highly significant for detecting and locating the disease, differentiating between benign and malignant nodules and establishing the aggressiveness and vascularity of pulmonary lesions. Therefore, partly in consideration of the substantial time and cost reduction of the single examinations, we believe that PET/MDCT with contrast administration will take on a increasingly central role in the diagnostic workup tiva correlazione tra la densità media microvascolare nei tumori maligni polmonari, il picco di attenuazione alla TC e l'uptake dell'imaging PET con $\left[{ }^{18} F\right]-F D G ~[35]$. Esiste una stretta correlazione tra il tempo di duplicazione espressione della rapidità di crescita delle lesioni polmonari maligne, il grado di potenziamento dopo somministrazione di MdC organo-iodato, correlato alla vascolarità tumorale, e la concentrazione del $\left[{ }^{18} \mathrm{~F}\right]-F D G[36]$.

In conclusione, per quanto riguarda l'obiettivo del nostro studio, la PET/TC, in base allo Standardised Uptake Value $(S U V)$, utilizzando un cut-off superiore a 2,5 e confrontandolo con il reperto istologico, ha riportato una sensibilità (Se) del 76,9\%, una specificità (Sp) del 100\%, un'accuratezza diagnostica pari a $89,2 \%$ con un valore predittivo positivo (VPP) del $100 \%$ ed un valore predittivo negativo (VPN) pari a 83,3\%; in relazione al calcolo del TD (cut-off $<400$ giorni) ha presentato una Se del 76,9\%, una Sp del 93,3\%, una accuratezza del 85,7\%, con un VPP del 90,9\% e un VPN del $82,3 \%$; in base al grado di potenziamento post-contrastografico (cut-off $\geq 15 \mathrm{UH}$ ) ha evidenziato una Se del 92,3\%, una Sp del 100\%, una accuratezza del 96,4\%, un VPP del 100\% e un VPN del 93,7\%; $i$ valori delle grandezze significative, attestano la crescente capacità della TCms con MdC e della $\left[{ }^{18} \mathrm{~F}\right]-F D G$-PET associate tra loro ed acquisite contemporaneamente, di migliorare sensibilmente l'analisi differenziale del NPSi, distinguendo lesioni benigne da lesioni maligne con un VPP del 91\%-100\% e un VPN del 83\%-93\%. I valori complessivi di Se e Sp della PET-TC sono stati del 92,3\% e $100 \%$ rispettivamente. Tali dati devono essere, comunque, confermati da campioni più ampi.

Un limite del nostro studio è relativo alle dimensioni medie dei noduli polmonari che, nella nostra casistica, è relativamente elevato $(1,8 \pm 1,2 \mathrm{~cm}$ per le lesioni maligne e $2 \pm 1$ $\mathrm{cm}$ per quelle benigne) e che può avere facilitato il rilievo dei parametri da noi utilizzati. È però possibile ritenere che l'aggiornamento tecnologico delle apparecchiature PET, con rilevatori di più piccole dimensioni, consentirà, con analoga o superiore accuratezza, di riconoscere e caratterizzare metabolicamente noduli polmonari di minori dimensioni. Inoltre nelle nostra casistica non vi è stata incidenza di lesioni nodulari polmonari non solide o sub-solide anche se è da considerare la minore percentuale di patologia eteroplasica con tali caratteristiche.

\section{Conclusioni}

In conclusione, il nostro studio conferma che la PET-TC permette di effettuare un'accurata analisi delle correlazioni anatomo-morfologiche e metabolico-funzionali del NPSi, consentendo di ottenere dati altamente significativi in relazione alla evidenziazione e localizzazione del processo patologico, alla diagnosi differenziale tra nodulo polmonare maligno e benigno, al grado di aggressività della neoplasia e al grado di vascolarizzazione di una lesione polmonare. Pertanto, anche in considerazione della notevole riduzione dei tempi e dei costi complessivi dei singoli esami, possiamo ritenere che la PET-TCms con MdC organo-iodato, svolgerà 
and treatment of lung cancer, above all in the preclinical phase.

In addition to the purely diagnostic value of this sophisticated integrated imaging modality, we can hypothesise an application for predictive prognostic stratification. This will be made possible by the development of new drugs, now being evaluated in advanced-phase trials, based on the use of monoclonal antibodies directed against specific growth factors and their receptors in pulmonary tumours. un ruolo sempre più preponderante nel percorso diagnostico-terapeutico del cancro polmonare soprattutto in fase preclinica.

Oltre al valore puramente diagnostico di tale sofisticato imaging integrato, è possibile ipotizzare una sua applicazione anche in senso predittivo prognostico considerando l'impiego di nuovi farmaci, in avanzata fase di studio, basati sull'utilizzo di anticorpi monoclonali diretti contro specifici fattori di crescita ed i loro recettori nei tumori polmonari.

\section{References/Bibliografia}

1. von Schulthess GK, Steinert AC, Hany TF (2006) Integrated PET/TC: current applications and future directions. Radiology 238:405-422. DOI 10.1148/radiol.2382041977

2. Hany TF, Steinert HC, Goerres GW et al (2002) PET diagnostic accuracy: improvement with in-line PET-TC system: initial results. Radiology 225:575-581. DOI 10.1148/radiol.2252011568

3. Lardinois D, Weder W, Hany TF et al (2003) Staging of non-small-cell lung cancer with integrated positron-emission tomography and computed tomography. N Engl J Med 348:2500-2507

4. Antoch G, Saoudi N, Kuehl H et al (2004) Accuracy of whole-body dualmodality fluorine-18-2-fluoro-2-deoxyD-glucose positron emission tomography (FDG-PET/CT) for tumor staging in solid tumors: comparison with $\mathrm{CT}$ and PET. J Clin Oncol 22:4357-4368

5. Tuddenham WJ (1984) Glossary of terms for thoracic radiology: recommendations of the Nomenclature Committee of the Fleischner Society. AJR Am J Roentgenol 143:509-517

6. Fletcher JW (2002) PET scanning and solitary pulmonary nodule. Semin Thorac Cardiovasc Surg 14:268-274

7. Diederich S, Wormanns D, Semik M et al (2002) Screening for early lung cancer with low-dose spiral CT: prevalence in 817 asymptomatic smokers. Radiology 222:773-781

8. Swensen SJ, Jett JR, Hartman TE et al (2003) Lung cancer screening with CT: Mayo Clinic experience. Radiology 226:756-761

9. Valanis BG (1996) Epidemiology of lung cancer: a worldwide epidemic. Semin Oncol Nurs 12:251-259
10. Ost D, Fein AM, Feinsilver SH (2003) The solitary pulmonary nodule. N Engl J Med 348:2535-2542

11. Cummings SR, Lillington GA, Richard RJ (1986) Estimating the probability of malignancy in solitary pulmonary nodules. A Bayesian approach. Am Rev Respir Dis 134:449-452

12. Zerhouni EA, Stitik FP, Siegelman SS et al (1986) CT of the pulmonary nodule:a cooperative study. Radiology 160:319-327

13. Shields TW (1993) Surgical therapy for carcinoma of the lung. Clin Chest Med 14:121-147

14. Nesbitt JC, Putnam JB, Walsh GL, Roth JA, Mountain CF (1995) Survival in early-stage lung cancer. Ann Thorac Surg 60:466-472

15. Swensen SJ, Viggiano RW, Midthun DE et al (2000) Lung nodule enhancement at CT: multicenter study. Radiology 214:73-80

16. Kostis WJ, Yankelevitz DF, Reeves AP et al (2004) Small pulmonary nodules: reproducibility of three-dimensional volumetric measurement and estimation of time to follow-up CT. Radiology 231:446-452

17. Feragalli B, Guido F, Larici AR et al (2005) Il nodulo polmonare. Radiol Med 110:294-316

18. Revel MP, Lefort C, Bissery A et al (2004) Pulmonary nodules: preliminary experience with three-dimensional evaluation. Radiology 231:459-466

19. Lillington GA (2001) Solitary pulmonary nodules: new wine in old bottles. Curr Opin Pulm Med 7:242-246

20. Jennings SG, Winer-Muram HT, Tarver RD, Farber MO (2004) Lung tumor growth: assessment with CT-comparison of diameter and cross-sectional area with volume measurements. Radiology 231:866-871
21. Revel MP, Bissery A, Bienvenu M et al (2004) Are two-dimensional CT measurements of small noncalcified pulmonary nodules reliable? Radiology 231:453-458

22. Lowe VJ, Fletcher JW, Gobar L et al (1998) Prospective investigation of positron emission tomography in lung nodules. J Clin Oncol 16:1075-1084

23. Gould MK, Maclean CC, Kuschner WG et al (2001) Accuracy of positron emission tomography for diagnosis of pulmonary nodules and mass lesions:a meta-analysis. JAMA 285:914-924

24. Kim BT, Kim Y, Lee KS et al (1998) Localized form of bronchioloalveolar carcinoma:FDG-PET findings. Am J Roentgenol 170:935-939

25. Collins VP, Loeffler RK, Tivey $\mathrm{H}$ (1956) Observations on growth rates of human tumors. Am J Roentgenol Radium Ther Nucl Med 76:988-1000

26. Nathan MH (1974) Management of solitary pulmonary nodules: an organized approach based on growth rate statistics. JAMA 227:1141-1144

27. Warburg O, Wind F, Negleis E (1930) On the metabolism of tumors in the body. In: Warburg O (ed) The metabolism of tumours. Constable, London, pp 254-270

28. Gallagher BM, Fowler JS, Gutterson NI (1978) Metabolic trapping as a principle of radiopharmaceutical design:some factors responsible for the biodistribution of $\left[{ }^{18} \mathrm{~F}\right]$ 2-deoxy-2fluoroD-glucose. J Nucl Med 19:1154-1161

29. Nolop KB, Rhodes CG, Brudin LH et al (1987) Glucose utilization in vivo by human pulmonary neoplasms. Cancer 60:2682-2689 
30. Abe Y, Matsuzawa T, Fujiwara T et al (1990) Clinical assessment of therapeutic effects on cancer using $\left[{ }^{18} \mathrm{~F}\right]$ 2-deoxy-2fluoro-D-glucose and positron emission tomography: preliminary study of lung cancer. Int J Radiat Oncol Biol Phys 19:1005-1010

31. Kubota K, Matsuzawa T, Fujiwara T et al (1990) Differential diagnosis of lung tumor with positron emission tomography: a prospective study. J Nucl Med 31:1927-1932
32. Di Chiro G, DeLa Paz RL, Brooks RA et al (1982) Glucose utilization of cerebral gliomas measured by $18 \mathrm{~F}$ fluoro-deoxyglucose and positron emission tomography. Neurology 32:1323-1329

33. Minn H, Joensuu H, Ahonen A (1988) Fluorodeoxyglucose imaging: a method to assess the proliferative activity of human cancer in vivo. Comparison with DNA flow cytometry in head and neck tumors. Cancer 61:1776-1781

34. Yamashita K, Matsunobe S, Tsuda T et al (1995) Solitary pulmonary nodule:preliminary study of evaluation with incremental dynamic CT.

Radiology 194:399-405
35. Tateishi U, Nishihara H, Tsukamoto E, Morikawa T, Tamaki N, Miyasaka K (2002) Lung tumors evaluated with FDG-PET an dynamic-CT:the relationship between vascular density and glucose metabolism. J Comput Assist Tomogr 26:185-190

36. Winer-Muram HT (2006) The solitary pulmonary nodule. Radiology 239:34-49. 10.1148/radiol.2391050343 